\title{
ZROZUMIAŁOŚĆ PRZEKŁADU TEKSTÓW UŻYTKOWYCH: AUTOMATYCZNA ANALIZA TŁUMACZEŃ ULOTEK LEKÓW NA CUKRZYCE
}

\section{ANNA BĄCZKOWSKA}

\section{READABILITY OF TRANSLATED FUNCTIONAL TEXTS: AN AUTOMATED ANALYSIS OF PATIENT INFORMATION LEAFLETS FOR DIABETES}

ABSTRACT The article presents results of a corpus-assisted study of diabetes medicines Patient Information Leaflets written in English and their translations into Polish. Several computer programs were used (Sketch Engine, Jasnopis, Coh-Metrix, Oleander Studio) in order to find out which text aspects affect the readability of these leaflets. The study combined the methodology of classical readability tests, a corpus-driven lexical analysis as well as automated text analysis. The correlation between traditional tests and the lexicosyntactic analysis was checked. Moreover, lexical aspects of texts which have the strongest influence on text readability were determined. A parallel corpus was compiled in order to compare the results obtained for the corpus of Polish leaflets with those retrieved from the corpus of English leaflets. The frequency of select words was determined with the aid of the British National Corpus, Narodowy Korpus Jezzyka Polskiego as well as the plTenTen15 corpus. It was noticed that both the English leaflets and their translations had a low readability level.

KEY WORDS readability, patient information leaflets, corpus-assisted analysis, diabetes, translation, medical discourse, parallel corpus, BNC, NKJP, plTenTen12, localization

CONTACT Nicolaus Copernicus University in Torun, Center for Specialized Languages in Medicine; anna.baczkowska@cm.umk.pl 


\section{1 / CZYTELNOŚĆ ULOTEK LEKÓW ORAZ ICH PRZEKŁAD}

Czytelność, określana też jako zrozumiałość tekstu, jego jasność, klarowność, dostępność itp., jest tematem bardzo rzadko podejmowanym przez polskich badaczy, choć niewątpliwie zainteresowanie nim rośnie ${ }^{1}$. W Stanach Zjednoczonych, w Wielkiej Brytanii i w Szwecji szczególnie intensywnie rozwija się ruch zwany Plain Language Campaign, propagujący używanie przez urzędy, banki i służbę zdrowia oraz inne instytucje użytku publicznego prostego, ogólnie zrozumiałego języka. Tematyka czytelności w języku polskim podjęta była przez Walerego Pisarka już w latach 60. XX w., który zaproponował wzór obliczający czytelność tekstów prasowych napisanych w języku polskim.

Najbardziej jednak znanym testem wśród polskich badaczy określającym zrozumiałość tekstu jest prawdopodobnie Gunning Fog (test na tzw. indeks mglistości), który zalecany jest ekspertom oceniającym podręczniki szkolne planowane do publikacji (Gąsiorek i in. 2014). W przewodniku dla rzeczoznawców zawierającym kryteria oceny podręcznika szkolnego (Gąsiorek i in. 2014) czytamy, że dla języka polskiego wyrazy trudne zdefiniowano jako czterosylabowe lub dłuższe (dla języka angielskiego są to wyrazy trzysylabowe) oraz że według współczynnika Gunninga idealny stopień mglistości tekstu to wartość 7 lub 8, podczas gdy wynik powyżej 12 oznacza, że przeciętny czytelnik będzie miał trudność w zrozumieniu tekstu. Ekspertom, mającym zdecydować, czy dany podręcznik nadaje się do użytku szkolnego, zaleca się ręczne obliczanie wskaźnika mglistości na dowolnym fragmencie tekstu liczącym 100 słów. Jest to słaba strona tego przewodnika, bowiem fragmenty przypadkowo wybrane przez ekspertów mogą się zasadniczo różnić od siebie. Analiza taka powinna być prowadzona automatycznie i na całym korpusie tekstu podręcznika.

Temat czytelności ulotek przekładanych na język polski jest bardzo rzadko podejmowany, choć jest niezwykle istotny. Niezrozumienie ulotki może bowiem skutkować poważnym uszczerbkiem na zdrowiu osoby czytającej ulotkę do leku, który zażywa, dlatego kwestia ta jest uregulowana prawnie. Zgodnie z Rozporządzeniem Ministra Zdrowia (Dz. U. 85, poz. 551) z dnia 26 kwietnia $2010 \mathrm{r}$. ulotki leków powinny być poprzedzone pilotażowymi badaniami czytelności przeprowadzonymi przez podmiot odpowiedzialny za wdrożenie danego leku na rynek na co najmniej trzech osobach i badaniami właściwymi przeprowadzonymi na co najmniej 10 osobach, z których każda powinna wykazać się zrozumieniem ulotki na poziomie $90 \%$.

Dokumentem nadrzędnym dla tego Rozporządzenia jest Dyrektywa EU 92/27/EEC dotycząca nazywania produktów leczniczych, która wymaga, aby ulotki leków pisane były w sposób jasny i zrozumiały dla pacjentów oraz aby były czytelne w językach oficjalnych krajów UE, w których dany lek jest wprowadzony na rynek („The package leaflet must be written in clear and understandable terms for the patient and be clearly legible in the official language or languages of the Member State where the medical product is placed on the market", Article 8).

W roku 2009 Unia Europejska wydała przewodnik na temat czytelności ulotek (Guideline on the Readability of the Labelling and Package Leaflet of Medical Products for Human Use, dalej:

$1 \quad$ W niniejszym artykule, podobnie jak w Jasnopisie (Gruszczyński i Ogrodniczuk 2015), określenia te będą używane zamiennie. Należy jednak zwrócić uwagę na fakt, że czytelność zasadniczo dotyczy cech tekstu, natomiast na przykład zrozumiałość odnosi się raczej do cech czytelnika (jego zdolności poznawczych, wiedzy, oczekiwań i nastawienia do tekstu, poziomu edukacji i znajomości tematu itp.) i jego interakcji z tekstem, np. tempa czytania tekstu, szybkości reakcji w testach na asocjacje itd. (zob. Garner i in. 2012). 
Przewodnik), w którego rozdziale I szczegółowo omówiono zalecany stopień czytelności treści ulotek. Treść ulotek dla pacjentów ma być zrozumiała dla osób o słabych umiejętnościach czytania i pisania, dla młodzieży, a nawet dzieci („If the package leaflet is well designed and clearly worded, this maximizes the number of people who can use the information, including older children and adolescents, those with poor literacy skills and those with some degree of sight loss.”). Powinno zatem używać się: słów zawierających jedynie kilka sylab, krótkich zdań i krótkich paragrafów oraz strony czynnej. Ponadto, powinno się unikać skrótów, a terminy medyczne powinny być tłumaczone i objaśnione w języku znanym pacjentom w danym kraju. Należy też podawać najpierw termin ogólny, zrozumiały przez laików, wraz z jego opisem, bezpośrednio po którym podaje się termin medyczny (,...lay term with a description first and the detailed medical term immediately after"; rozdz. I w Przewodniku). Zalecane jest również skracanie dystansu między autorem ulotki, a jego czytelnikiem poprzez używanie zaimków osobowych i dzierżawczych, np. take care with X ifyou have asthma („bądź ostrożny, zażywając leku X, jeśli chorujesz na astmę”), a także używanie formy your medicine („twój lek”) zamiast powtarzać nazwę leku.

W większości opracowań na temat klarowności tekstów medycznych ich zrozumiałość jest mierzona klasycznymi wzorami na czytelność. Są to wzory statystyczne, na przykład Gunning Fog, Flesch Reading Ease, Raygor Estimate itp. Wzory te mierzą czytelność w sposób mechaniczny, za podstawę obliczeń przyjmując stosunek takich parametrów, jak liczba sylab w słowie, liczba słów w zdaniu, paragrafie czy całym tekście oraz liczba zdań w tekście. Trudno jednak szacować stopień klarowności tekstów, koncentrując się jedynie na wyżej wymienionych parametrach, które określają trudność tekstu, zliczając ich cechy nielingwistyczne, tj. niedotyczące leksyki, semantyki, psycholingwistyki, składni, cech tekstu itd., i uwzględniając jedynie wartości numeryczne sylab, słów i zdań. Badania klasyczne łatwo jest podważyć, ponieważ na przykład nie każde słowo długie jest trudne i nie każde słowo krótkie jest łatwe. Termin apnoea (bezdech) jest krótkim słowem, ale ogólnie nieznanym niespecjalistom, natomiast cardiology jest długim słowem ogólnie rozpoznawalnym i zrozumiałym. Podział zdań długich na kilka krótszych i upraszczanie słownictwa z kolei może nawet utrudnić zrozumienie tekstu (Davison i Kantor 1982, Wolfer i in. 2015).

Krytyka badań nad czytelnością opartych jedynie na klasycznych wzorach jasności tekstu kontestuje takie mechaniczne podejście do analizy tekstu. Przyczyn jest wiele: badania te mają nieprawidłowo skonstruowane ramy metodologiczne, wyniki na czytelność mogą się znacząco różnić w zależności od zastosowanego testu, nie są one w stanie uwzględnić trudności tekstu na poziomie konceptualnym dla czytelnika, nie biorą pod uwagę stopnia znajomości tematyki tekstu przez czytelnika, koncentrują się jedynie na strukturze powierzchniowej języka, ignorują organizację, strukturę i spójność tekstu, a także umiejętności pisarskie autora oraz nie uwzględniają wiedzy encyklopedycznej, oczekiwań i kompetencji czytelnika, a także nie mają walidacji psycholingwistycznych, np. czasu reakcji na słowa w badaniach asocjacyjnych czy interakcji zachodzącej między tekstem a jego czytelnikiem (Bormuth 1966, Gilliland 1968, Stokes 1978, Bruce i in. 1981, Davidson i Kantor 1982, Davidson i Green 1988, Buchbinder i in. 2001, Clerehan i in. 2005, Garner i in. 2012, Iluk 2012, Leroy i in. 2013, Charzyńska i in. 2015, Crossley i in. 2016, Crossley i in. 2019, Bączkowska 2019, Bączkowska a, Bączkowska b).

Stanowisko dotyczące analizy zrozumiałości tekstu, głoszące, że badając złożoność tekstu należałoby jednak przyjrzeć się również jego parametrom językowym wydaje się logiczne 
i uzasadnione. Mimo iż pisał już o tym John Bormuth w połowie lat sześćdziesiątych (proponując konkretne parametry językowe, które powinny być uwzględnione w analizie czytelności), to dopiero od niedawna zmienne leksykalno-syntaktyczne włączane są do badań czytelności, bowiem wraz z rozwojem narzędzi oferowanych przez przetwarzanie języka naturalnego i rozwojem językoznawstwa komputerowego i korpusowego, szczegółowa analiza czytelności w oparciu o parametry językowe na zbiorach tekstów stała się stosunkowo łatwa do zrealizowania.

Analiza czytelności ulotek dla pacjentów nie cieszy się zbyt dużym zainteresowaniem wśród badaczy, a istniejące opracowania dotyczą na przykład: ewaluacji zrozumiałości ulotek leków przez ekspertów i pacjentów (Gustafsson i in. 2003), analizy czytelności ulotek leków w oparciu o badania ankietowe (Charnock i in. 1999, Pander Maat i Lentz 2010), formulowania treści ulotek zgodnie z zasadami językoznawstwa systemowo-funkcjonalnego Hallidaya w celu poprawienia ich czytelności (Clerehan i in. 2005 i Clerehan i in. 2009, Clerehan 2014), badania stopnia zrozumienia i reakcji pacjentów na informacje dotyczące ryzyka zażywania wybranych leków (Herber i in. 2014), porównania czytelności ulotek na przestrzeni 12 lat w Danii (Aksehave i Zethsen 2014), upraszczania tekstu ulotek w stosunku do ich tekstów źródłowych, jakimi są charakterystyki leków (Wermuth 2016), walidacji zrozumiałości ulotek opracowanych według nowych standardów zaproponowanych przez autorów badania (Sekhar i in. 2017), zastosowania klasycznego testu na czytelność w badaniu czytelności ulotek z Wielkiej Brytanii i ze Stanów Zjednoczonych (Hadjipavlou i in. 2013). Badania te koncentrują się na rozumieniu i interpretacji tekstu przez czytelników (badania Charnocka, Gustafssona, Clerehan, Pander Maata i Lentza, Herbera, Aksehave i Zethsen, Sekhara), rzadziej na parametrach samego tekstu. ${ }^{2}$

Badanie zaprezentowane $\mathrm{w}$ niniejszym artykule nie analizuje kompetencji czytelnika ulotki, jest natomiast przykładem na analizę tekstów, ti. koncentruje się na opisie (deksrypcji) aspektów lingwistycznych (i w pewnym stopniu kulturowych) zbioru (korpusu) ulotek. Celem korpusowych badań deskryptywnych jest przedstawienie charakterystyki dyskursu poprzez identyfikację powtarzających się wzorców form leksykalnych czy struktur syntaktycznych w zbiorze tekstów. W przypadku niniejszego studium opisowi podlega dyskurs medyczny³, zarówno w tekstach oryginalnych, jak i w ich przekładach. Analiza dyskursu może też polegać na szukaniu korelacji i/lub dokonywaniu porównań ilościowych między oryginałem i jego przekładem w zbiorze tekstów w obrębie konkretnych kategorii opisu, np. użycia strony biernej, stosunku przymiotników do rzeczowników itp.

Niniejsze studium odwołuje się zatem do teorii przekładu deskryptywnego znanego jako Descriptive Translation Studies (DTS; Toury 1995, Toury 2012), początkowo stosowanej tylko do

2 Bormuth 1966 badał szereg cech leksykalno-syntaktycznych, Clerehan i in. 2005 analizowali na przykład gęstość leksykalną ulotek, Wermuth również opisała gęstość leksykalną oraz strategie upraszczania tekstu zgodne z zasadami lokalizacji, Hadjipavlou zastosował jeden wzór klasyczny (Flesch-Kincaid) do mierzenia czytelności tekstów.

3 Dyskurs medyczny obejmuje nie tylko teksty tradycyjnie z nim utożsamiane tj. przeznaczone dla lekarzy (artykuły naukowe, przewodniki dla klinicystów itp.), nasycone medyczną terminologią specjalistyczną, ale też teksty użytkowe oraz teksty związane z medycyną, np. strony internetowe przeznaczone dla pacjentów, telewizyjne programy dokumentalne na temat zdrowia, broszury dla pacjentów; a także teksty z zakresu biologii molekularnej, weterynarii, farmakologii, pielęgniarstwa, zdrowia publicznego itp., które jednak łączy to, że mają ścisły związek z tematyką zdrowia i choroby, że przekazują rzetelne i dokładne informacje oraz że używają (w różnym stopniu) terminologii specjalistycznej (Montalt i González-Davis 2007: 21, Montalt 2011: 79). 
przekładów literackich, jednak później również do innych typów tekstów (Kruger i Wallmach 1997). Badania deskryptywne są obiektywne, nieoceniające i mają na celu opisanie oraz przedstawienie wyjaśnień aktualnego stanu rzeczy. Dzięki identyfikacji pewnych powtarzających się wzorców, DTS ma na celu określenie prawdopodobieństwa ich występowania w określonych warunkach, dlatego też DTS dąży do formułowania zasad pozwalających wysunąć pewne uogólnienia (Toury 2012: 10). DTS promuje zatem badania empiryczne i retrospektywne. Warto podkreślić, że mimo iż celem DTS nie jest określanie, jak powinno wyglądać „prawidłowe” tłumaczenie tylko odkrywanie norm w przekładach docelowych, to jednak DTS nie wyklucza zastosowania obserwacji wyplywających $\mathrm{z}$ tej metody $\mathrm{w}$ thumaczeniu stosowanym (Applied Translation Studies), tj. w praktyce tlumaczy (Toury 2012: 11). Jest to jednak - według Toury'ego - zadanie dla praktyków przekładu, nie zaś cel badań naukowych translatoryki (Translation Studies), w tym DTS.

Podejście do analizy tłumaczeń promowane przez DTS przeciwstawiane jest analizie preskryptywnej i normatywnej typowej dla lat 70. XX w. (Kruger 2002: 77). Podejście preskryptywne zwykle koncentruje się na ocenie pejoratywnej, na wyrażaniu krytyki na temat nieprawidłowo dokonanych tłumaczeń (użycia złych ekwiwalentów), tj. „deformacji” (Chesterman 2010: 38-39), i udzielaniu wskazówek, czy wręcz określaniu, jak należy tłumaczyć dane terminy czy struktury i frazy. Badania preskryptywne, jakościowe, które są mocno krytykowane przez DTS, a które nadal dominują w analizach języka medycznego, mają znaczenie głównie dla dydaktyki przekładu. W swojej wersji zorientowanej na funkcje, DTS koncentruje się na kontekście, w szczególności na wpływie przetłumaczonych tekstów na język i kulturę docelową, a ekwiwalencję zastępuje normami. Przekładoznawstwo deskryptywne przeniosło punkt ciężkości z tekstu źródłowego na tekst i kulturę docelową oraz z badań głównie jakościowych prowadzonych na pojedynczych jednostkach analizy (słowach, frazach, zdaniach) na badania głównie ilościowe. W uzyskiwaniu celów DTS niezwykle pomocne okazało się językoznawstwo korpusowe rozwijane od lat 60. XX w., które do przekładoznawstwa wprowadzone zostało (jako Corpus-based Translation Studies) na początku lat 90. XX w. przez Monę Baker (1993), co uważane jest za linię demarkacyjną zwrotu z przekładoznawstwa preskryptywnego na deskryptywne (Tymoczko 1998).

Oprócz DTS, podstawą teoretyczną niniejszych rozważań będzie też podejście do przekładu znane pod nazwą lokalizacja (ang. localization). Głównym celem tłumaczeń w duchu lokalizacji jest przybliżenie tekstu źródłowego docelowemu odbiorcy, przy czym dotyczy to nie tylko warstwy werbalnej (np. przekładu słownictwa, kolokacji, idiomów czy terminów specjalistycznych typowych dla języka docelowego), ale też warstwy graficznej i kulturowej (Pym 2001). Lokalizacja ma zatem zwykle charakter multimodalny. Zwrot od nadawcy (tekstu źródłowego, autora) do odbiorcy (tekstu docelowego i jego czytelnika/widza) w teorii przekładu nie jest zjawiskiem nowym, rozpoczął się już w latach 60 . XX w. i przyjmował różne formy i nazwy, na przykład jako teoria Skopos czy strategia thumaczeniowa znana jako udomowienie (domestykacja) (Venuti 1995). Stanowił też podstawy wyżej wymienionej teorii DTS. Lokalizacja nie jest jednak tożsama z teorią Skopos (Vermeer 1982) czy domestykacją, choć niewątpliwie te trzy podejścia łączy to, że punktem ciężkości przekładu jest odbiorca (a nie autor) oraz, że nacisk położono na kontekst językowo-kulturowo-społeczny tekstu docelowego.

Lokalizacja odnosi się przede wszystkim do tłumaczenia produktów (samo pojęcie pochodzi z teorii marketingu), które mają być wprowadzane na nowe rynki zbytu. Tradycyjnie 
lokalizacja, zwłaszcza ta zorientowana na przekład praktyczny, kojarzona jest z produktami cyfrowymi, w szczególności z grami komputerowymi i stronami internetowymi producentów i produktów (Esselink 2000: 1, Schäler 2010). Istnieją jednak też opracowania ukierunkowane na aspekty teoretyczne lokalizacji (Pym 2001, O'Hagan i Ashworth 2002, Wermuth 2016), które nie ograniczają lokalizacji do gier i stron internetowych, a przekład uznają jako główny element składowy adaptacji produktu (i jego dokumentacji) dla odbiorcy docelowego w komunikacji międzykulturowej, tj. jego oczekiwań i potrzeb. Adaptacja wymaga dostosowania tekstu oryginalnego do zarówno języka, jak i kultury docelowej. W propozycji C. Wermuth (2016), która dotyczy przekładu intralingwalnego języka medycznego, lokalizacja (a z nią adaptacja) wymaga też zmiany języka ekspertów na język powszechnie zrozumiały. Lokalizacja pozwala na wprowadzanie zasadniczych zmian w produkcie (jego opisie, wyglądzie czy grafice opakowania) w procesie dopasowywania go do nowego rynku zbytu. Ponadto lokalizacja zakłada, że już na etapie produkcji eliminuje się czynniki mogące utrudnić internacjonalizację produktu (O’Hagan i Ashworth 2002: x). W przypadku niektórych produktów, w szczególności gier komputerowych, proces przekładu inicjuje się nawet równolegle do tworzenia wersji oryginalnej produktu (Esselink 2000: 2), od początku zakłada się bowiem, że dany produkt będzie przekładany (adaptowany) na wiele języków i sprzedawany na różnych międzynarodowych rynkach lokalnych (stąd nazwa lokalizacja).

Leki są niewątpliwie przykładem produktu, który już na etapie planowania produkcji zakłada przygotowanie go na różne lokalne rynki zbytu, posługujące się odmiennymi językami i reprezentujące wielorakie kultury. Dlatego też, ulotki dołączone do leków powinny być modyfikowane w stosunku do swojej wersji początkowej (zwykle w języku angielskim), tak aby dopasować produkt (ulotki do leku) do preferencji konsumentów pochodzących z konkretnego rynku zbytu (rozumianego w kategoriach geograficznych i kulturowych). W celu zwiększenia ich sprzedaży na lokalnych rynkach można stosować przekład ulotek leków oparty w pewnym stopniu na strategiach typowych dla lokalizacji. Tłumaczenie ulotek leków można zatem uznać za pewną formę lokalizacji z uwagi na istnienie elementu internacjonalizacji, zakładającego już na etapie produkcji przekład jednego głównego tekstu na wiele innych (globalizacja produktu), oraz z uwagi na potrzebę adaptacji tekstu oryginalnego do kontekstu społeczno-kulturowego obowiązującego na danym rynku zbytu. Treść ulotki leku jest tylko jednym z elementów podlegającym lokalizacji. Inną formą adaptacji produktu do nowych rynków jest też modyfikacja grafiki ulotki oraz opakowania produktu, co w przypadku leków jest częstym zabiegiem. Modyfikacji mogą ponadto podlegać zmiany $\mathrm{w}$ charakterze i wielkości czcionek w ulotce czy pewne zmiany $\mathrm{w}$ organizacji struktury tekstu (jednak nie wychodzące poza przepisy dotyczące struktury ulotki).

\section{2 / METODY BADAWCZE}

Analizy korpusu danych liczących wiele tekstów nie sposób uczynić bez korzystania z programów komputerowych, które są o tyle pomocne, że potrafią bardzo szybko obliczyć setki parametrów, nierzadko korzystając z dość skomplikowanych wzorów. Stosunkowo nowym programem opracowanym do analizy języka polskiego, z którego korzystałam w niniejszych badaniach, jest Jasnopis. Dla języka angielskiego istnieje bardzo dużo programów do obliczania złożoności tekstów, nie wszystkie są godne polecenia, niektóre wymagają wysokich parametrów sprzętu 
komputerowego, aby działały poprawnie i płynnie, a nawet znajomości podstaw programowania; jednak ich ogromną zaletą jest to, że dostarczają one danych obliczonych dla kilkuset indeksów, co pozwala na rzetelną analizę ilościową dużej liczby tekstów. W poniżej przedstawionym badaniu wykorzystałam programy Coh-Metrix, Sketch Engine i Jasnopis, o których szerzej napiszę w następnej sekcji. Niniejsze opracowanie łączy zatem klasyczne wzory na czytelność tekstów z analizą językoznawczą tekstu. Jest to podejście stosunkowo nowe do badań nad czytelnością w odniesieniu do tekstów w języku angielskim i promowane od kilku lat przez niektórych badaczy, w tym językoznawców (zob. m.in. Garner i in. 2012, Gruszczyński i Ogrodniczuk 2015, Bailin i Grafstein 2016, Crossley i in. 2016, Crossley i in. 2019, Bączkowska 2019, Bączkowska a, Bączkowska b), mimo iż krytyka badań czytelności za pomocą testów klasycznych zasygnalizowana już była kilka dekad temu (Bormuth 1966, Gilliland 1968, Stokes 1978, Davidson i Kantor 1982, Davidson i Green 1988 itd.).

W celu przeprowadzenia analizy czytelności ulotek leków na cukrzycę wykorzystano kilka programów komputerowych. Program Readability Oleander Studio (v. 2019) pozwolił dokonać obliczeń według tradycyjnych wzorów czytelności (Flesch Reading Ease, Gunning Fog, Raygor Estimate). Jasnopis (jasnopis.pl, Gruszczyński i Ogrodniczuk 2015) to aplikacja, która oferuje obliczenia indeksów leksykalnych dla tekstów w języku polskim (różnorodność leksyki, wyrazy trudne i rzadkie, klasa trudności tekstu, stosunek rzeczowników do czasowników itp.). W celu dokonania obliczeń indeksów leksykalnych tekstów w języku angielskim zastosowano program Coh-Metrix (McNamara i in. 2014). Komercyjny system zarządzania korpusami Sketch Engine (dalej SE; www.sketchengine.co.uk) pozwolił z kolei zidentyfikować i obliczyć liczbę przymiotników w różnych funkcjach w zdaniu, stronę bierną, rzeczowniki odsłowne oraz konstrukcje z bezokolicznikiem. Dodatkowo, charakterystyki frekwencyjne zaczerpnięte zostały z danych British National Corpus (dalej BNC) i Narodowego Korpusu Języka Polskiego (NKJP), a także z korpusu plTenTen12.

Spośród licznych klasycznych wzorów służących do obliczania czytelności tekstów w niniejszym badaniu wykorzystano cztery: Gunning Fog (GF), Raygor Estimate (RE), Flesch Reading Ease (FRE) i wzrór Walerego Pisarka (P). Gunning Fog jest przystosowany do języka polskiego (dostępny w programie Jasnopis; dalej GFJ). Wzór na GF dla języka angielskiego (Gunning 1952), zwany również indeksem mglistości, przedstawiono poniżej:

$$
\text { Indeks mglistości (GF) =0,4 } \times(\text { ŚS+\%SD), }
$$

gdzie ŚS to średnia długość zdania w słowach, a \%SD to procent słów długich. Dla tekstów w języku angielskim wykorzystano również wzór Raygor Estimate (1977), który oblicza jasność tekstu w oparciu o stosunek średniej liczby sylab w wyrazach i liczby wyrazów w zdaniu na 100 słów. Wzór Pisarka (1969) i Flescha (1948) podano poniżej:

$$
\text { Wzór Pisarka: } T=\frac{\sqrt{T_{s}^{2}-T_{w}^{2}}}{2}
$$

gdzie $\mathrm{T}$ to trudność, $\mathrm{T}_{\mathrm{s}}$ to procent wyrazów powyżej trzech sylab (forma hasłowa), a $\mathrm{T}_{\mathrm{w}}$ średnia liczba wyrazów w zdaniu.

$$
\text { Wzór Flescha: }(206,835-1015) \times \text { ŚDZ-84,6 × ŚLSyl, }
$$

gdzie ŚDZ to średnia długość zdania, z ŚLSyl to średnia liczba sylab w wyrazie. 
Coh-Metrix jest zaawansowanym programem komputerowym do wielopoziomowej automatycznej analizy spójności i zrozumiałości tekstów, który za podstawy teoretyczne przyjął wybrane teorie i modele lingwistyczne, i który korzysta z korpusów językowych. Określenie stopnia zrozumiałości opiera się na ponad stu indeksach analizujących tekst na kilku poziomach (słowa, składni, tekstu, modelu sytuacyjnego, gatunku tekstu i retoryki). Program ten oblicza również zrozumiałość tekstu według tradycyjnych wzorów, w tym Flesch Reading Ease (dalej FRE), Flesch-Kincaid, a także korzysta z własnego wzoru Coh-Metrix $\mathrm{L}_{2}$ Readability.

Jasnopis jest programem komputerowym łączącym klasyczne wzory czytelności z analizą językoznawczą, który opracowano dla języka polskiego. Co prawda liczba indeksów jest dość ograniczona w porównaniu z programem Coh-Metrix, jednak Jasnopis w chwili obecnej, o ile mi wiadomo, oblicza najwięcej indeksów dla języka polskiego. Za materiał referencyjny przy obliczaniu słów trudnych i rzadkich program ten przyjął listę ok. 5 tysięcy słów sporządzoną przez Janusza Imiołczyka (1987) dla języka polskiego, a utworzoną na bazie pięciu małych słowników (Gruszczyński i Ogrodniczuk 2015: 60-61). Jest to aspekt wymagający dopracowania, jak przyznają sami autorzy Jasnopisu (Gruszczyński i Ogrodniczuk 2015: 62). Dla porównania, programy zaprojektowane dla języka angielskiego obliczając wyrazy rzadkie odwołując się do kilku (zwykle wielomilionowych) korpusów językowych, a wyniki dzielą na kilka poziomów frekwencyjnych z progiem co 1000 słów, co daje o wiele bardziej precyzyjne obserwacje. Oprócz GF Jasnopis wykorzystuje też wzór na czytelność Walerego Pisarka (dalej wzór P). W niniejszych badaniach wzory Pisarka i Flescha nie wykazały jednak korelacji $(r=-0,360, p=0,3068$, $\mathrm{p}<0,10$ ), w związku z tym wzór Flescha nie będzie używany do porównania ulotek oryginalnych $\mathrm{z}$ ich polskimi tłumaczeniami.

\section{3 / KORPUS DANYCH}

Korpus ulotek składa się z dwóch podkorpusów: podkorpusu ulotek w języku polskim (dalej KUP lub korpus UP) i podkorpusu ulotek w języku angielskim (dalej KUA lub korpus UA). Korpus UP to oficjalne tłumaczenia ulotek z języka angielskiego (zgromadzonych w korpusie UA). Treść ulotek w języku polskim uzyskano ze strony rządowej Rejestr Produktów Leczniczych (http://leki.urpl.gov.pl/index.php), a treść ulotek w języku angielskim - ze strony zawierającej informacje o lekach wprowadzonych na rynek brytyjski „Leki” (www.medicines.org.uk). Ulotki są zunifikowane tematycznie i dotyczą cukrzycy. Wszystkie aktualizowane były w roku 2019 (ulotki podlegają aktualizacji raz na rok). Przeanalizowano ulotki napisane dla następujących leków: Jardiance, Forxiga, Invocana, Pioglitazone, Glucobay (Acarbose), Gliklazide, Glimepiride (Amaryl), Glipizide, Bydureon oraz Lyxumia. Wybór takiego, a nie innego schorzenia nie był podyktowany żadnymi kryteriami wstępnymi. Istotne dla badania było jedynie zachowanie spójności tematycznej ulotek oraz istnienie $\mathrm{w}$ formie elektronicznej dwóch wersji ulotek: w języku angielskim i polskim.

Zanim przebadano teksty w korpusie, usunięto $\mathrm{z}$ nich metadane (informacje o producencie, podmiocie odpowiedzialnym, adresy, numery kontaktowe itp.) oraz przekonwertowano je na pliki o rozszerzeniu txt i zapisano w kodach rozpoznawalnych przez użyte w analizie programy komputerowe. Odrzucono 5 tekstów, których nie znaleziono w internecie w obu językach w tych samych wersjach i/lub w wersji czytelnej dla zastosowanych programów komputerowych. 
Ostatecznie analizie poddano 10 ulotek w języku polskim, liczących w sumie 21103 słów, oraz 10 ulotek w języku angielskim, liczących 27894 słów. Średnia liczba słów w polskich ulotkach wynosi 2107 słów, a w ulotkach napisanych w języku angielskim 2307 (dane według systemu SE). Wielkość całego korpusu (KUP i KUA) równa jest zatem około 50000 słów (dane według syste$\mathrm{mu}$ SE). Cały korpus ulotek ma postać elektroniczną, został poddany segmentacji, tokenizacji i parsowaniu, dzięki czemu możliwe było przeprowadzenie automatycznej, ilościowej analizy tekstów z wykorzystaniem zaawansowanych narzędzi z zakresu przetwarzania języka naturalnego. Utworzono korpus równoległy z ulotek oryginalnych i ich tłumaczeń na język polski, co było pomocne w analizie jakościowej tłumaczeń.

\section{4 / WYNIKI BADAŃ}

\section{1 / Czytelność ulotek w języku polskim}

„Klasa trudności tekstu” to ogólny wynik dla analizowanego tekstu zaproponowany przez twórców Jasnopisu, który określa poziom trudności tekstu, tj. jego czytelność (dalej J, tj. według Jasnopisu). Wyniki J w całym korpusie ulotek w języku polskim (dane parametryczne) wahały się od 4 do 6 (na 10 możliwych punktów, gdzie 10 oznacza tekst bardzo trudny, a 1 - tekst bardzo łatwy). Wartość J równa 4 oznacza, że tekst jest zrozumiały dla osób z wykształceniem średnim (liceum) lub mającym duże doświadczenie życiowe, wartość J równa 5 przypisana jest tekstom dla osób z wykształceniem wyższym zawodowym (licencjat), a wartość 6 to teksty trudne w odbiorze, zrozumiałe dla osób z wykształceniem wyższym (magisterskim). Innymi słowy, badane ulotki dostępne są dla osób, które ukończyły od 12 do 17 lat edukacji, przy czym są tylko trzy teksty zrozumiałe dla absolwentów liceów (czyli te najprostsze w badanym korpusie) (Ryc. 1).

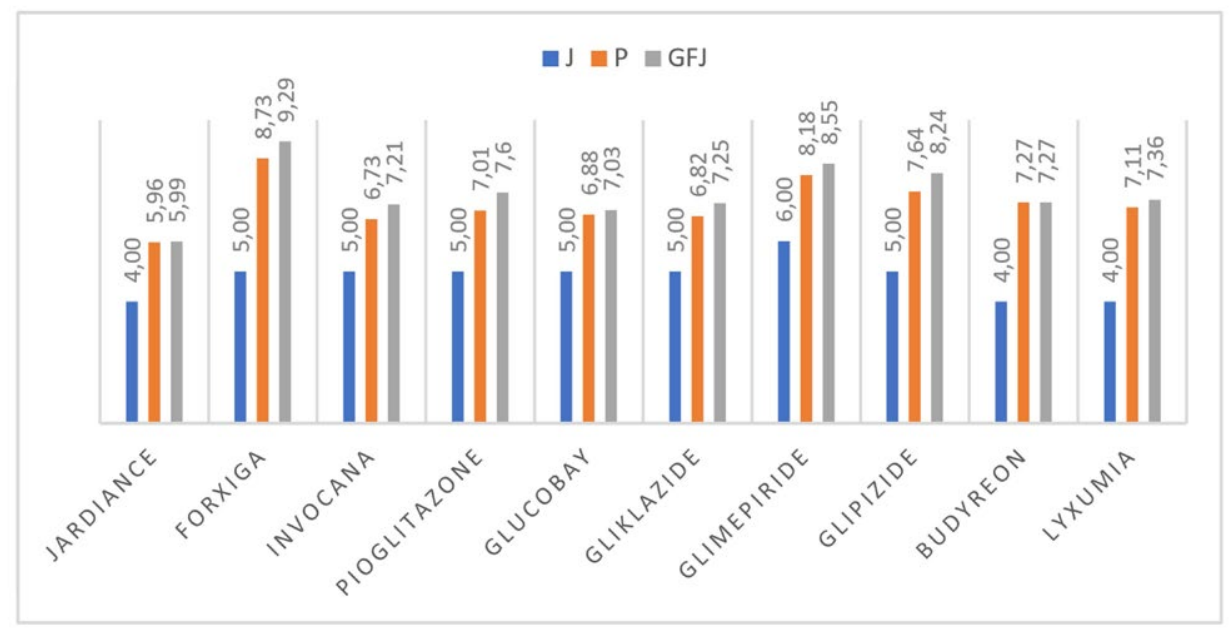

Ryc. 1. Porównanie indeksów ] (Jasnopis), P (wzór W. Pisarka) i CF] (Cunning Fog dla tekstów polskich) 
Jednym z parametrów składowych wartości J jest indeks mgły, czyli formuła Gunning Fog przystosowana do języka polskiego (GFJ). Co ciekawe, rezultaty uzyskane dla GFJ są zbieżne z wartościami uzyskanymi dla indeksu opracowanego przez Walerego Pisarka (indeksu liniowego, hasłowego) $(r=0,9759, \mathrm{p}=0,0001, \mathrm{p}<0,01)$. Wartości dla GPJ wahają się między około 6 a 9 , natomiast dla P między wartościami około 6 a 8. Wynik dla testu GFJ świadczy o niskiej czytelności badanych tekstów. Zgodnie z opisem Pisarka z kolei wartość 6 oznacza teksty „bardzo łatwe” (poziom czytelności jak w czasopismach „Przyjaciółka” i „Tina”), a dla 7 i 8 teksty „łatwe” (poziom czytelności jak w „Małym Gościu Niedzielnym”). Średnia dla wartości uzyskanych w teście Pisarka wynosi 4,8. Odpowiada to poziomowi mniej więcej drugiego roku studiów, zatem badane teksty są trudne w odbiorze (tj. mało czytelne). Jak już wcześniej wspomniano, wzór Pisarka opiera się na wzorze Flescha (Gruszczyński i Ogrodniczuk 2015: 29), trzeba jednak pamiętać, że przeciwnie do Flescha Pisarek nie wliczał nazw własnych do grupy wyrazów trudnych, dlatego wyniki Flescha i Pisarka nie są paralelne. Nie stwierdzono korelacji między wartościami uzyskanymi $\mathrm{w}$ teście Pisarka i teście Flescha dla polskich tekstów $(r=-0,306$, $\mathrm{p}=0,3898, \mathrm{p}<0,10)$. Stwierdzono jednak korelację $(r=0,6797, \mathrm{p}=0,0306, \mathrm{p}<0,5)$ między indeksem mgły przystosowanym dla języka polskiego (GFJ) i indeksem mgły opracowanym dla języka angielskiego (GF). Przyjmując, że testy te są porównywalne, można stwierdzić, że czytelność poszczególnych tekstów oryginalnych jest podobna do ich tłumaczeń. Dla tekstów w języku angielskim nie ma odpowiednika wartości J, dlatego będzie on analizowany jedynie przy porównaniach różnych ulotek w obrębie języka polskiego.

Jasnopis pozwolił także uzyskać dane dotyczące słów rzadkich oraz słów trudnych. W niniejszym badaniu te dwa parametry nie są ze sobą skorelowane, tzn. że wyrazy trudne nie zawsze są rzadkie. Ponadto, zgodnie z oczekiwaniami, potwierdzono przewidywany wynik, że stopień czytelności tekstu jest bezpośrednio zależny od procentu liczb trudnych w stosunku do wszystkich słów oraz od liczby wyrazów rzadkich $(r=0,8009, \mathrm{p}=0,0053, \mathrm{p}<0,5)$, co potwierdza zasadność wyników uzyskiwanych w niektórych klasycznych testach na czytelność tekstów.

Niektórzy badacze zakładają (Gruszczyński i Hadryan 2015), że duża liczba rzeczowników w stosunku do czasowników zwiększa niezrozumiałość tekstu. Wykres poniżej (Ryc. 2) ilustruje wyniki otrzymane dla stosunku liczby rzeczowników do czasowników (Rz/Cz) oraz wynik indeksu mgły dla wszystkich tekstów. Wynik ich korelacji nie jest statystycznie znaczący $(r=0,2497, \mathrm{p}=0,4866, \mathrm{p}<0,05)$. Dane pozwalają wnioskować, że mała liczba czasowników w stosunku do rzeczowników niekoniecznie oznacza, że dany tekst jest mało zrozumiały. Crossley i in. (2017) wykazali nawet tendencję odwrotną, tzn. że mała liczba czasowników promowała czytelność tekstu. Nie wykazano też korelacji między wynikami dla stosunku $\mathrm{Rz} / \mathrm{Cz}$ z ogólną kategorią klasy trudności tekstu $\mathrm{J}(r=0,3051, \mathrm{p}=0,3913, \mathrm{p}<0,05)$. 


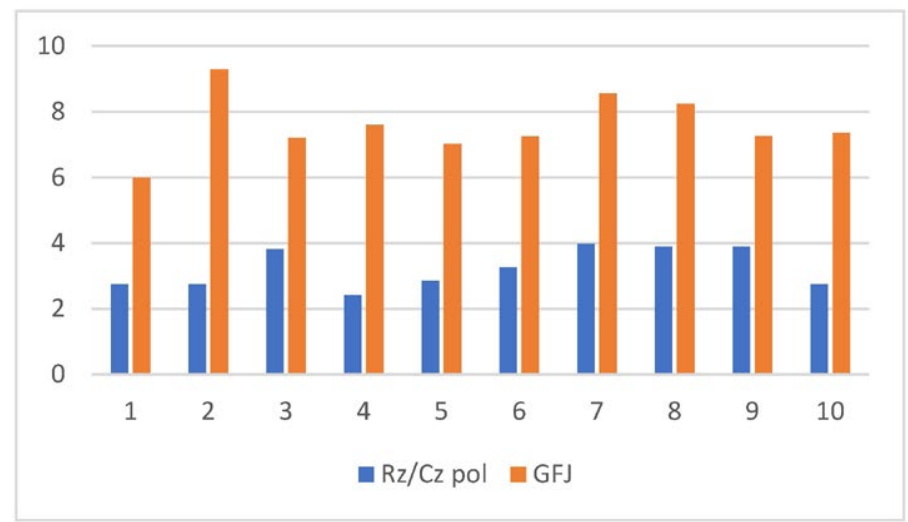

Ryc. 2. Stosunek rzeczowników do czasowników w ulotkach angielskich i ich polskich tłumaczeniach

W dalszej części analizy wyszukano te rzeczowniki, które są zakończone na -ość oraz -c/s/zja, a także rzeczowniki odsłowne (do tego celu wykorzystano Sketch Engine). Zwykle ilustrują one rzeczowniki abstrakcyjne, które uznawane są za mające negatywny wpływ na czytelność tekstu (Gruszczyński i Hadryan 2015: 48). Rzeczowniki abstrakcyjne wystąpiły w 6,8 tysiącach przypadkach na milion słów. W porównaniu z ulotkami w języku angielskim, gdzie rzeczowników kończących się na -tion jest 13,6 tysięcy na milion słów, wszystkich rzeczowników abstrakcyjnych jest około dwa razy mniej w ulotkach polskich niż w angielskich. Z kolei gerundium wystąpiło w 37,4 tysiącach słów na milion, struktur w bezokoliczniku jest 4,88\%, a przykładów na stronę bierną, która jest niezalecana w Przewodniku, jest 0,2\%.

Sprawdzono dodatkowo korelacje między liczbą czasowników a wartością J $(r=0,1773$, $\mathrm{p}=0,6241, \mathrm{p}<0,05)$ oraz liczbą czasowników a indeksem mgły $(r=0,5934, \mathrm{p}=0,0705, \mathrm{p}<0,01)$ i okazało się, że liczba czasowników nie ma wpływu na ogólny wynik czytelności tekstu J, jednakże ma pewien wpływ na indeks mglistości. Można więc stwierdzić, że częstość występowania czasowników nie ma decydującego znaczenia dla czytelności tekstu, choć korelacje występowania czasowników z wynikiem jednego z testów na czytelność (np. z indeksem mglistości) należałoby sprawdzić na większej liczbie tekstów w celu uzyskania jednoznacznej odpowiedzi.

Istnieje natomiast pewien związek między wynikiem określającym stosunek liczby rzeczowników do czasowników $(\mathrm{Rz} / \mathrm{Cz})$ i procentem wyrazów trudnych $(r=0,6791, \mathrm{p}=0,0308$, $\mathrm{p}<0,05)$, co sugeruje, że wyrazy trudne to zwykle rzeczowniki.

Stosunek rzeczowników do przymiotników (Rz/Prz) z kolei jest pozytywnie skorelowany z klasą trudności tekstu (parametr J) $(r=0,766, \mathrm{p}=0,0097, \mathrm{p}<0,05)$, tzn. że duża liczba rzeczowników w stosunku do przymiotników zwykle pociąga za sobą większą trudność w zrozumieniu tekstu. Innymi słowy, im mniej przypada przymiotników na jeden rzeczownik, tym trudniejszy tekst. Mogłoby się zatem wydawać, że obecność przymiotników może działać na korzyść czytelnika, zwiększając dostępność treści ulotek. Jednakże nie potwierdza tego korelacja między liczbą przymiotników w tekście a liczbą $\mathrm{J}(r=0,3198, \mathrm{p}=0,3677, \mathrm{p}<0,01)$. Co więcej, istnieje korelacja pomiędzy indeksem mglistości dla tekstów polskich i ogólną liczbą przymiotników w nich występujących $(r=0,6442, \mathrm{p}=0,4439$, p < 0,05), z której wynika, że wyższa frekwencja przymiotników w ulotkach zmniejsza jej czytelność. 
Celem sprawdzenia, w jakim wypadku przymiotnik pogarsza czytelność tekstu, przeanalizowano korelacje między wartością J z jednym i z dwoma przymiotnikami w prepozycji występujące w różnych funkcjach w zdaniu (obliczonymi z wykorzystaniem systemu Sketch Engine). Analizie poddano konteksty, w których frazy z jednym lub dwoma przymiotnikami zawierały przymiotniki w funkcji przydawki atrybutywnej charakteryzującej lub klasyfikującej. Odległość między rzeczownikiem a przydawką (tzw. slope) oznaczająca w tym przypadku miarę rozproszenia wyrazów w zdaniu, ustawiono do jednego miejsca, tzn. slope ustawiono na -1. Dzięki temu frazy typu niebezpieczny jednakże lek, skuteczny w badaniach lek czy znany na świecie lek nie były brane pod uwagę, bowiem slope w tego typu frazach wynosi od -2 do -4 , co oznacza, że przydawka może się znaleźć dwa, trzy lub cztery wyrazy na lewo od rzeczownika (w lewym kontekście), a między nimi mogą pojawić się jeden, dwa lub trzy inne wyrazy nie brane pod uwagę w analizie. Przypadki, kiedy slope był wyższy niż 2 zignorowano w niniejszym studium, gdyż system mógłby wygenerować przypadkowe przymiotniki nienależące do kolokacji z kluczowym rzeczownikiem. Ponadto, sprawdzono też przymiotniki w funkcji przydawki predykatywnej będącej orzecznikiem (slope 2). Wszystkie te funkcje przymiotnika porównano również $\mathrm{z}$ wynikami indeksu mglistości. Wyniki statystycznie znaczące otrzymano jedynie w przypadku korelacji J z przymiotnikiem w postpozycji w funkcji klasyfikującej: im wyższy wynik J, tym więcej przymiotników w postpozycji $(r=0,7165, \mathrm{p}=0,1969, \mathrm{p}<0,05)$. Innymi słowy, w tekstach o mniejszej czytelności występuje więcej przymiotników klasyfikujących. Związane jest to z popularnymi kolokacjami dotyczącymi tematyki medycznej i/lub diabetologicznej (przykłady z korpusu UP: problemy zdrowotne, objawy niepożądane, substancja czynna, poradnia cukrzycowa, leki przeciwcukrzycowe, dieta cukrzycowa), które nie powinny jednak przysparzać zbyt dużo kłopotów przeciętnemu czytelnikowi, ponieważ są to utarte wyrażenia lub zwroty, które charakteryzują się stosunkowo dużym stopniem łączliwości i/lub wysoką frekwencją.

Inne frazy z przymiotnikiem ilustrują z kolei terminologię medyczną (np. lek przeciwzakrzepowy, tkanka łączna, kwasica ketonowa, obrzęk naczynioruchowy, kamica żółciowa, karmeloza sodowa, diwodorofosforan jednowodny). Mimo iż te frazy również charakteryzują się dużym stopniem łączliwości (jak wynika z danych uzyskanych z NKJP, czasami nawet wyższym niż kolokacje wcześniej wymienione, tj. problemy zdrowotne itd.), to jednak są to terminy fachowe i zazwyczaj mają niską frekwencję w języku ogólnym, dlatego to właśnie głównie te przymiotniki, jako komponenty fachowych terminów, wpływały niekorzystnie na ocenę czytelności tekstów w programie Jasnopis.

Jeśli chodzi o rzeczowniki trudne, to Jasnopis zidentyfikował je w danych KUP między $5 \%$ a 10\% (średnia 6,5\%), najwięcej w ulotce leku o nazwie Glimepiride, i są to zwykle nazwy chemiczne, np. dyzopiramid, dehydrogenaza, lub nazwy jednostek stanów chorobowych, np. hiperglikemia, hipoglikemia, granulocytopenia itd. Mimo iż zgodnie z Przewodnikiem terminy medyczne mogą się pojawić w ulotkach dla pacjentów (w nawiasie, bezpośrednio po nazwie nieeksperckiej, następującej po objaśnieniu znaczenia), to w ulotce do tego leku nie wszystkie terminy medyczne są wyjaśniane:

(1) „...leki wspomagające wytwarzanie moczu (diuretyki), saluretyki, leki stymulujące tarczycę..."

(2) „...mogą wystąpić: stan splątania (delirium), drgawki...”. 
Eksplikacje te nie są oczywiste, np. przeciętny czytelnik może mieć problem z wyobrażeniem sobie „stanu splątania” (splątanie występuje w 9 na 10 ulotek) przy jednoczesnym rozumieniu słowa trudnego (pod względem okurencji na listach frekwencyjnych), jednak bardziej rozpoznawalnego, jakim jest delirium, które używane jest potocznie i środowiskowo w formie delirka. Słownik języka polskiego (sjp.pl) podaje następującą definicję słowa delirium: „stan zaburzenia świadomości połączony z podnieceniem ruchowym, bredzeniem i halucynacjami”. $Z$ kolei rzadko który pacjent będzie rozumiał słowo saluretyki (leki usuwające z nerek jony sodu i potasu), którego nie objaśniono, podczas gdy częściej używane słowo diuretyki zostało zdefiniowane. Co ciekawe, odpowiednika słowa saluretyk nie ma w oryginale, jest jedynie określenie thiazide diuretics (water tablets) czyli „tiazydowe leki moczopędne (tabletki wzmagające wydalanie moczu)”, które powodują zwiększanie wydalania wody i elektrolitów z organizmu (do elektrolitów wliczamy sód i potas). Tłumacz zamienił zatem mało zrozumiały termin leki tiazydowe na równie mało zrozumiały termin saluretyki. Przyczynę takiego zabiegu trudno wyjaśnić. W tekście oryginalnym trudny termin medyczny thiazide diuretics zastąpiono bardzo przystępnym water tablets.

Wydaje się, że wysoka wartość słów trudnych uzyskana w programie Jasnopis może wynikać z braku konsekwencji w objaśnianiu terminów medycznych oraz z mało zrozumiałych objaśnień tych terminów. Częstsze podawanie definicji lub objaśnień powinno zniwelować problem niskiej zrozumiałości tekstu.

W całym korpusie UP procent wszystkich słów trudnych jest silnie skorelowany z wartością J $(r=0,8188, \mathrm{p}=0,0037, \mathrm{p}<0,01)$. Równie silna korelacja zachodzi między procentem rzeczowników trudnych a parametrem $\mathrm{J}(r=0,8148, \mathrm{p}=0,0040, \mathrm{p}<0,01)$. Korelacji takiej nie znaleziono między trudnymi czasownikami i J, ani między trudnymi przymiotnikami a indek$\operatorname{sem~J~}(r=0,0619, \mathrm{p}=0,8651, \mathrm{p}<0,5)$. Zatem, im więcej słów trudnych i im więcej rzeczowników trudnych, tym mniejsza zrozumiałość tekstu obliczana przez Jasnopis. Wynika z tego, że rzeczowniki miały znaczący wpływ na ocenę tekstu jako niezrozumiałego.

\section{2 / Czytelność ulotek w języku angielskim - porównanie z ulotkami w języku polskim}

Test czytelności Raygor Estimate (RE) pozwolił zauważyć, że zrozumiałość ulotek w języku angielskim jest niejednolita, waha się od poziomu 9 klasy w szkole do poziomu studiów wyższych (college). Uwzględniając zalecenia amerykańskiego departamentu zdrowia (USDDH, 2010) przyjmującego klasę szóstą jako rekomendowany poziom czytelności, ulotki w języku angielskim napisane są zbyt skomplikowanym językiem. Inaczej jest w przypadku ulotek w języku polskim, gdzie większość wartości wskaźnika czytelności RE koncentruje się w polu odpowiadającym 12 klasie oraz na poziomie szkoły wyższej. Test RE nie jest dla języka polskiego zupełnie wiarygodnym parametrem w kwestii przedziału klasy. Wynika to z faktu, że RE opracowano dla języka angielskiego i że w języku polskim są generalnie dłuższe słowa (licząc w sylabach), a test RE opiera się na liczbie sylab w wyrazie (dlatego dla zminimalizowania tego problemu użyto form hasłowych słów polskich). Mimo to test ten wskazuje na większą jednorodność wyników czytelności (Ryc. 3 b.).

$\mathrm{Z}$ poprzedniej analizy tekstów polskich według kategorii tekstu Jasnopisu (wartość J) wynika, że ulotki te mają czytelność na poziomie między liceum (12 lat nauki) a ukończeniem 
studiów wyższych (17 lat nauki), co jest pozytywnie skorelowane z wynikami uzyskanymi dla tekstów polskich w programie RE $\left(r_{s}=0,6785, \mathrm{p}=0,0309\right)$, mimo iż korzystano w tym obliczeniu z wersji dla języka angielskiego.

Na rycinie poniżej RE o największej czytelności (punkt na granicy 11 i 12 klasy) to ulotka leku o nazwie Jardiance. Ten sam tekst uzyskał wartość świadczącą o największej czytelności w teście P i GFJ. W tym przypadku trudno jednak mówić o zbieżności wyników dla P/GFJ i RE, nie uzyskano bowiem korelacji dla tych parametrów w całym korpusie UP (dla GFJ: $r_{s}=0,3015$, $\mathrm{p}=0,3972$ ).

Podsumowując, w odniesieniu do całego korpusu można zauważyć, że w języku polskim jest większa unifikacja wartości indeksu RE, tzn. teksty ulotek są bardziej jednorodne pod względem (nie)zrozumiałości, podczas gdy w języku angielskim różnice w poziomach dostępności są bardziej zróżnicowane w obrębie badanych ulotek, tj. są większe różnice między poszczególnymi ulotkami pod względem klarowności tekstu (Ryc. 3.).

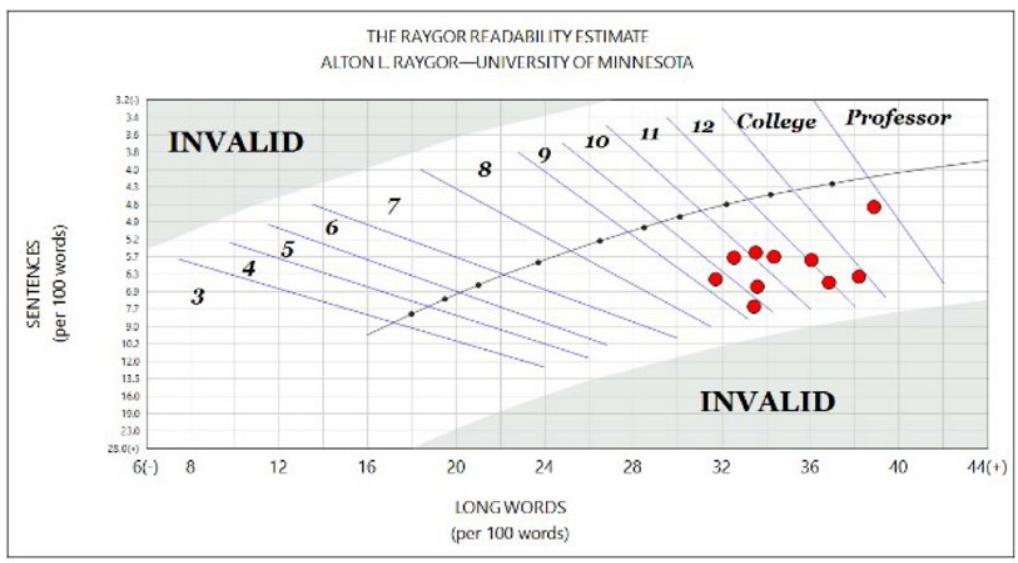

Ryc 3a. Raygor Estimate dla ulotek w języku angielskim

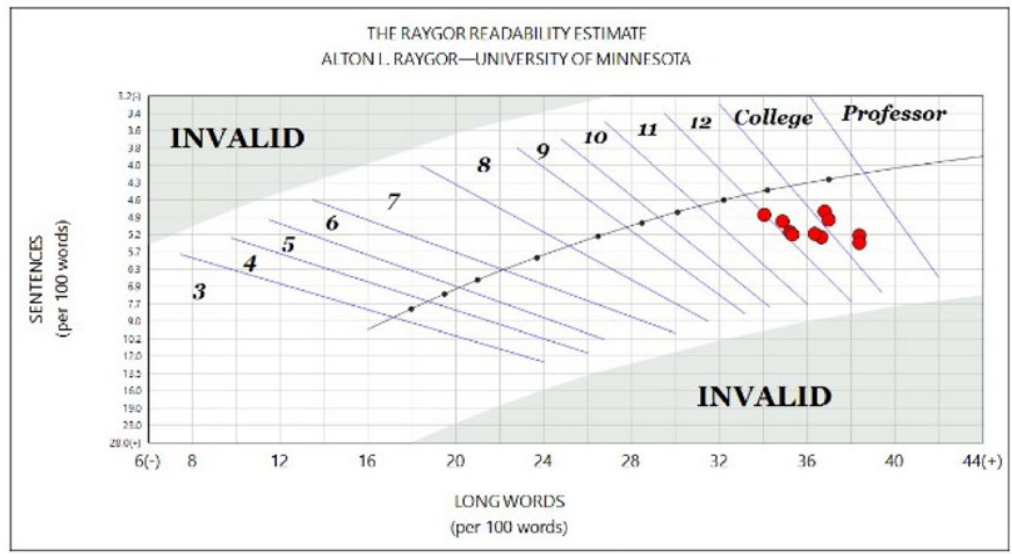

Ryc 3 b. Raygor Estimate dla ulotek w języku polskim 
Wartość FRE (indeks Flescha) dla ulotek w języku angielskim przedstawia rycina 4., z której wynika, że napisane są one językiem „dość trudnym” („fairly difficult”).

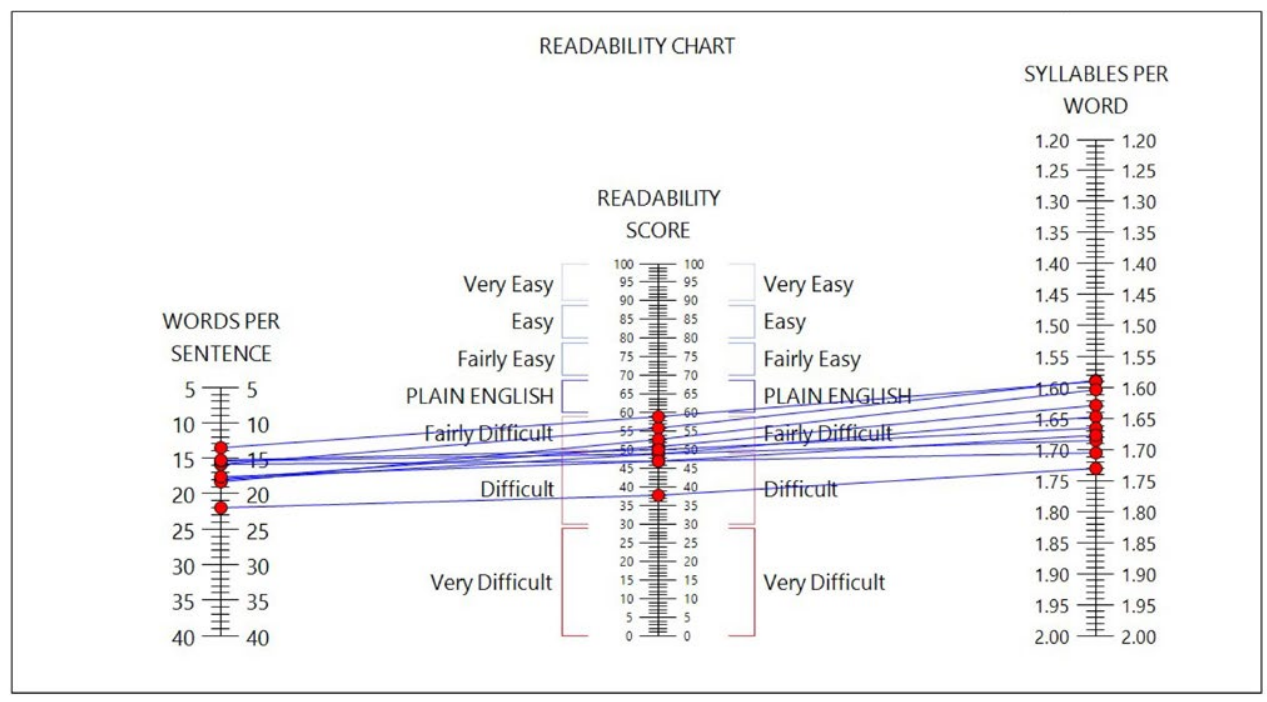

Ryc. 4. Czytelność ulotek angielskich według testu Flesch Readability Ease

Procent rzeczowników w ulotkach angielskich wynosi średnio około 14, czyli trzy razy mniej niż w ulotkach polskich (w polskich tekstach występuje średnio $45 \%$ rzeczowników). Interesujące jest to, że mimo wyższej okurencji rzeczowników w tekstach polskich, w sumie nie stwierdzono mniejszej czytelności tłumaczeń (zarówno teksty z KUP, jak i KUA są ogólnie na poziomie szkoły średniej i studiów wyższych).

Czasowników jest ok. $6 \% \mathrm{w}$ tekstach angielskich i około 15\% w tekstach polskich. Przymiotników jest z kolei ok. $4 \% \mathrm{w}$ ulotkach angielskich i ok. 14,5\% w ulotkach polskich. Stosunek rzeczowników do czasowników (Rz/Cz ang) jest w przypadku każdej ulotki oryginalnej niższy niż w przypadku ulotek w języku polskim (Rz/Cz pol, Ryc. 5a). Nie zaobserwowano korelacji między stosunkiem rzeczowników do czasowników a indeksem $G F\left(r_{s}=0,1890, p=0,6009\right)$ ani indeksem RE $(r=-0,267, \mathrm{p}=0,4558, \mathrm{p}<0,10)$.

Stosunek rzeczowników do przymiotników (Ryc. 5 b) w ulotkach angielskich (Rz/Prz ang) nie jest skorelowany z czytelnością tekstu $(r=-0,1849, \mathrm{p}=0,6108, \mathrm{p}<0,05$; GF: $r=-0,1596$, $\mathrm{p}=0,6608, \mathrm{p}<0,05)$. Liczba rzeczowników w stosunku do czasowników jest mniejsza w ulotkach angielskich niż polskich, natomiast liczba rzeczowników w stosunku do przymiotników jest wyższa w tekstach angielskich niż polskich. W ulotkach angielskich na około 2,5 rzeczownika przypada jeden czasownik, a około 3,5 rzeczownika przypada na jeden przymiotnik, podczas gdy w ulotkach polskich około 3,2 rzeczownika przypada na jeden czasownik i około 3,1 rzeczownika na jeden przymiotnik. 

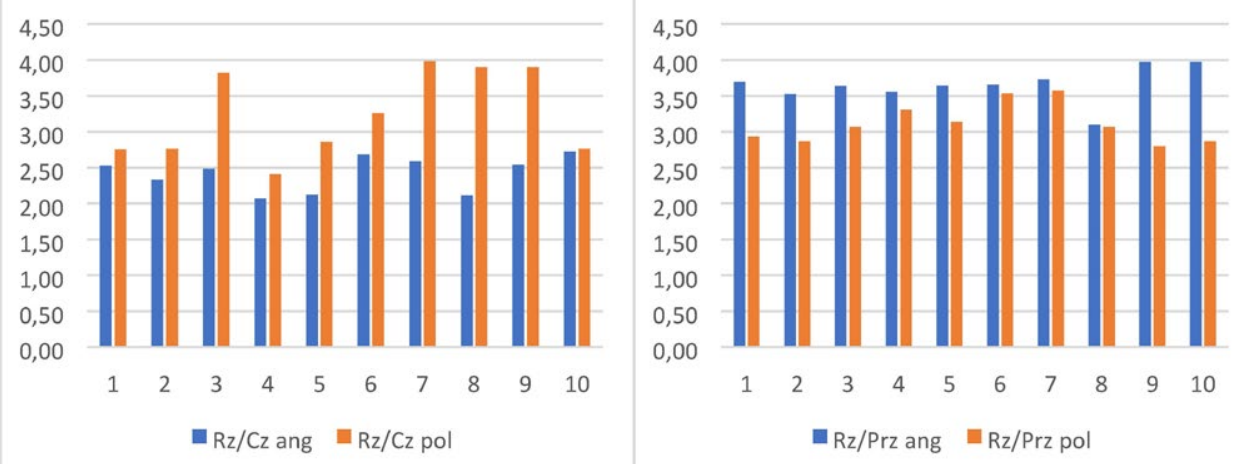

Ryc. 5 a. Stosunek rzeczowników do czasowników w ulotkach angielskich i ich polskich tłumaczeniach

Ryc. 5 b. Stosunek rzeczowników do przymiotników wulotkach angielskich $\mathrm{i}$ ich polskich tłumaczeniach

W ulotkach angielskich liczbę przymiotników atrybutywnych oraz predykatywnych porównano z wynikami testu Gunning Fog i okazało się, że jest niewielka korelacja wyników dla frazy z dwoma przymiotnikami atrybutywnymi w prepozycji z GF $(r=0,5872, p=0,7429, p<0,10)$, świadcząca o tym, że dwa przymiotniki w prepozycji mają tendencję do występowania w tekstach o mniejszej czytelności. Takiej korelacji nie stwierdzono w korpusie UP. Pozostałe korelacje z przymiotnikami są statystycznie nieznaczące.

Jak wcześniej wspomniano uważa się, że rzeczowniki odsłowne utrudniają zrozumienie tekstu. W ulotkach $\mathrm{w}$ języku angielskim występują one rzadziej niż w ich polskich tłumaczeniach: $\mathrm{KUA}=2,21 \%$ (KUP = 4,62\%). Z kolei struktur bezokolicznikowych, które są łatwiejsze w odbiorze niż gerundia, jest w KUA 1,39\% (w KUP zidentyfikowano ich 4,88\%), ponad trzy razy mniej niż w korpusie polskim.

Kolejnym aspektem wpływającym na czytelność tekstu jest użycie strony czynnej zamiast biernej. Zgodnie z zaleceniami Plain Language, Przewodnikiem UE oraz polską Ustawa o lekach, o których wspomniano we wstępie, w ulotkach należy unikać strony biernej. Ulotki w języku angielskim zawierają $0,35 \%$, a w języku polskim 0,2\% zdań $\mathrm{w}$ stronie biernej (dane po normalizacji). W ulotkach w języku angielskim jest co prawda mniej rzeczowników odsłownych, co przyczynia się do większej zrozumiałości tekstu, ale jednocześnie mniej struktur z bezokolicznikiem oraz więcej przypadków użycia strony biernej, co przyczynia się do zmniejszenia klarowności sensu w ulotkach. Z kolei w języku polskim jest więcej rzeczowników odsłownych niż w tekstach angielskich, ale zrozumiałość jest zwiększona dzięki częstszemu użyciu struktury bezokolicznikowej oraz rzadziej używanej strony biernej. Różnice te ilustruje Ryc. 6. 


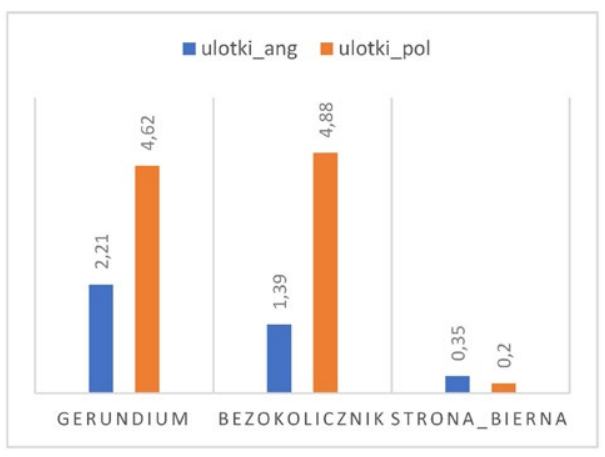

Ryc. 6. Procentowe wartości użycia gerundium, bezokolicznika i strony biernej

Trzeba jednak pamiętać, że okurencja strony biernej, gerundium i bezokolicznika jest ogólnie procentowo niska $\mathrm{w}$ całym tekście. $Z$ tego względu należy przyjrzeć się nie tyle liczbie ich okurencji, ile proporcjom między ich użyciem w języku angielskim i polskim (Ryc. 6.). Przykładów na gerundium jest dwa razy więcej w tłumaczeniach, bezokoliczników jest ok. 3,5 razy więcej $\mathrm{w}$ tekstach polskich, a strony biernej prawie dwa razy mniej w polskich ulotkach.

Zgodnie z zaleceniami omówionymi w Przewodniku, w ulotkach napisanych w języku angielskim powinno się zwracać do czytelnika w bezpośredni sposób celem zmniejszania dystansu między autorem ulotki a czytelnikiem (pacjentem) i tym samym zwiększenia przystępności tekstu. Styl ulotki powinien być zatem mniej formalny. Stąd często używanie formy you („ty”) czy your („twój”, „swój”), zamiast strony biernej czy formy bezosobowej oraz trybu rozkazującego $w$ drugiej osobie liczby pojedynczej w ulotkach w języku angielskim. Zaimek your występuje prawie 20 tys. razy na milion słów w korpusie ulotek napisanych $w$ języku angielskim. W korpusie polskich ulotek natomiast nie ma w ogóle przykładów na formę drugiej osoby liczby pojedynczej. Czasowników w 3 osobie liczby pojedynczej z kolei jest tylko 7,5 tysiąca na milion słów w KUA i aż 46 tysięcy na milion słów w KUP. Ewidentnie forma trzecioosbowa liczby pojedynczej często zastępuje w tekstach polskich formę drugiej osoby liczby pojedynczej występująca w tekstach $w$ języku angielskich. Kilka przykładów przedstawiono poniżej:

(1) You have diabetes because your body does not make enough insulin to control the level of sugar in your blood („Masz cukrzycę, ponieważ twój organizm nie produkuje wystarczającej ilości insuliny, aby kontrolować twój poziom cukru we krwi”),

(2) If you have any further questions, ask your doctor („Jeśli masz jeszcze jakieś pytania, zapytaj swojego lekarza"),

(3) If you get any side effects, talk to your doctor („Jeśli wystąpią u ciebie jakieś efekty uboczne, porozmawiaj ze swoim lekarzem"),

(4) Keep this leaflet („Zachowaj tę ulotkę"),

(5) Read all of this leaflet carefully („Przeczytaj uważnie całą ulotkę”),

(7) This medicine has been prescribed for you only („Ten lek został przypisany tylko tobie/ do twojego użytku").

Dla porównania, w korpusie z ulotkami w języku polskim w takich kontekstach używa się formy w trzeciej osobie liczby pojedynczej lub czasowników niewłaściwych, np. 
(1) Jeśli kobieta jest w ciąży lub karmi piersią, uważa że może być w ciąży lub planuje zajść w ciążę, powinna poprosić swojego lekarza lub farmaceutę o poradę przed zastosowaniem tego leku... („If a woman is pregnant or breast-feeding, thinks she may be pregnant, or is planning to have a baby, she should ask her doctor..."),

(2) Należy uważnie zapoznać się z treścią ulotki („One should carefully read this leaflet”).

Zaimek osobowy you w przykładzie (7) został zastąpiony rzeczownikiem kobieta, a w miejsce trybu rozkazującego w przykładzie (2) ask your doctor („zapytaj swojego lekarza”) użyto czasownika modalnego powinna poprosić swojego lekarza („[a woman] should ask a doctor”). Przykład (6) z kolei przetłumaczono na język polski w następujący sposób: Lek ten przepisano ściśle określonej osobie, zatem you („ty”) zastąpiono „ściśle określoną osobą”.

Zmiany te należy uznać za konsekwencje dostosowania tekstu źródłowego do odbiorcy docelowego i zasad komunikacji oraz zwyczajów społeczno-kulturowych obowiązujących na lokalnym rynku zbytu leków. Brak personalizacji w ulotkach w języku polskim jest zatem przykładem na lokalizację, bowiem nie jest ogólnie przyjęte w języku polskim i w komunikacji oficjalnej, aby zwracać się w tak bezpośredni sposób do adresata komunikatu, jak w języku angielskim, w którym zaimek you jest powszechnie używany. Zmiany takie są jednak zauważalne w reklamach leków w telewizji polskiej.

Podsumowując dotychczasowe rozważania, można zauważyć, że globalnie w całym tekście najistotniejsze różnice między ulotkami polskimi i angielskimi są widoczne w użyciu rzeczowników (których jest ok. cztery razy więcej w ulotkach polskich), czasowników (których jest ok. trzy razy mniej w tekstach polskich) i przymiotników (których jest ok. dwa razy więcej w tekstach polskich), a także w użyciu form bezosobowych i zaimków, natomiast pozostałe badane cechy tekstów wykazują mniejsze dysproporcje między oryginałami a ich tłumaczeniami (Ryc. 7.).

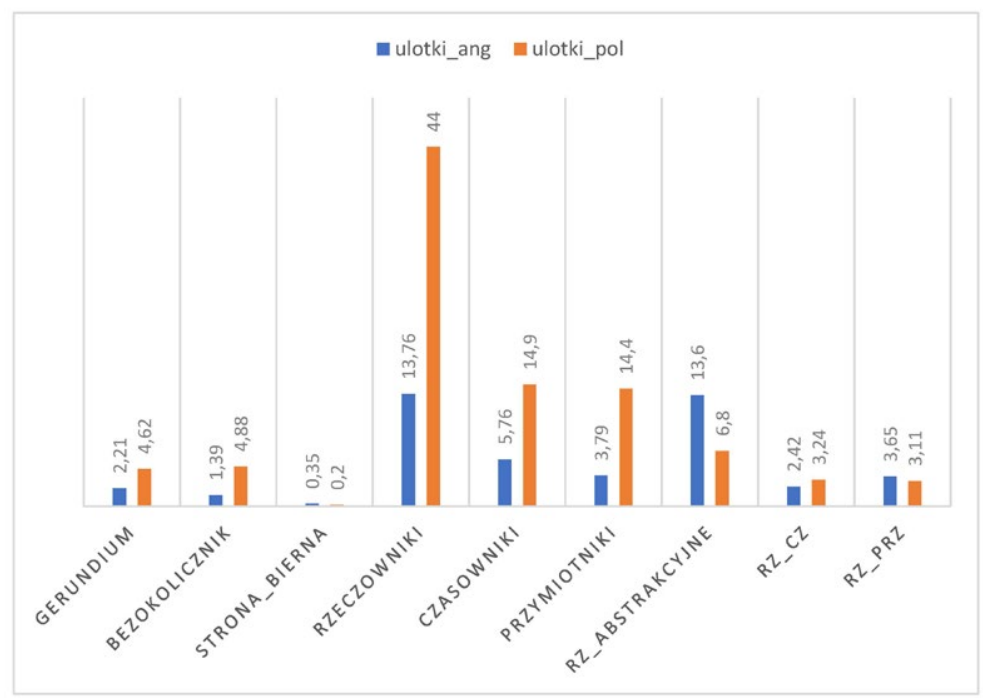

Ryc. 7. Wybrane aspekty leksykalne i syntaktyczne w ulotkach w języku angielskim i polskim 
Uwzględniając niską czytelność ulotek w języku angielskim, na podstawie dotychczasowej analizy można wstępnie stwierdzić, że w celu zwiększenia czytelności tekstów w języku polskim, na ile to możliwe, tłumacze powinni się przede wszystkim skoncentrować na zmniejszeniu liczby rzeczowników, także odczasownikowych - gerundiów oraz przymiotników. Ponadto, wskazane byłoby dalsze obniżenie użycia strony biernej oraz jeszcze częstsze używanie struktur z bezokolicznikiem. Zgodnie z zasadami przekładu opartego na lokalizacji, z uwagi na specyfikę komunikacji w języku polskim, promującą dystans między interlokutorami, nie jest wskazane zmniejszenie form bezosobowych i zwiększenie form czasownika w drugiej osobie liczby pojedynczej czy trybu rozkazującego w drugiej osobie liczby pojedynczej, jak to jest rekomendowane w Przewodniku. Uwzględniając proces lokalizacji, który powinien zachodzić w tłumaczeniu ulotek, klasyczne testy na czytelność nie mogą stanowić jedynego pomiaru czytelności tekstów porównywanych w różnych językach.

\section{3 / Przykładowe tłumaczenia ulotek}

Zgodnie z Przewodnikiem nazwy własne powinny być podawane w nawiasie, przed którym powinno znaleźć się ich objaśnienie. Zarówno w ulotkach angielskich, jak i polskich w większości przypadków zastosowano się do tego wymogu. Zdarzają się jednak sytuacje odwrotne, tj. kiedy podaje się nazwę własną (leku czy jednostki chorobowej), a następnie w nawiasie jej wyjaśnienie, a takie przypadki pojawiają się zarówno w ulotkach w języku angielskim, jak i polskim, np. „nausea (feeling sick)”, „flatulence (passing gas)”, „anticoagulants (used to treat blood clots)”; „niedrożność jelita (blokada w jelicie)”, „diuretyki (pomagające usunąć nadmiar wody z organizmu) lub (leki odwadniające)”, „afazja (zaburzenia zdolności mówienia)”. W przykładzie poniżej w polskiej ulotce w ogóle nie wyjaśniono co oznacza „ostra uogólniona osutka krostkowa”. Z kolei „trombocytopenia” wyjaśniona jest w nawiasie, podczas gdy zalecenia są takie, aby najpierw podawać definicję, a następnie termin fachowy w nawiasie. Nieznacznie więcej sytuacji niedostosowania się do wymogu podawania objaśnień przed nawiasem zawierającym termin medyczny znajduje się w ulotkach angielskich.

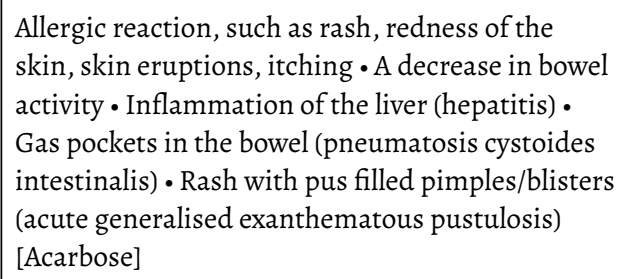

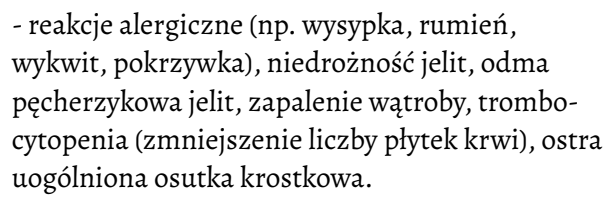
wykwit, pokrzywka), niedrożność jelit, odma pęcherzykowa jelit, zapalenie wątroby, trombocytopenia (zmniejszenie liczby płytek krwi), ostra uogólniona osutka krostkowa.

Przykład 3.

Jednocześnie jednak w ulotkach polskich można się spotkać z dopowiedzeniami (eksplicytacja), tj. fragmentami, których nie ma w oryginale. W przykładzie powyżej dodano trombocytopenię (zmniejszenie liczby płytek krwi), natomiast w przykładzie poniżej dodano „gdy pacjent jest w podeszłym wieku". Zabiegi te generalnie zwiększają czytelność tekstu. 
If you retain water (fluid retention) or have heart problems in particular if you are over 75 years old. [Pioglitazone]
- nastąpiło zatrzymanie wody w organizmie lub pacjent ma niewydolność serca, szczególnie gdy pacjent jest w podeszłym wieku (powyżej 75 roku życia).

Przykład 4.

W ulotkach polskich występują też uproszczenia polegające na przykład na pomijaniu uszczegółowień. Poniżej w przekładzie na język polski pominięto nazwy leków przeciwzapalnych (celecoxib, etoricoxib), określenie leków przeciwzapalnych („anti-inflammatory”) oraz fachową nazwę zatrzymania wody („fluid retention”) podaną w nawiasie w wersji angielskiej.

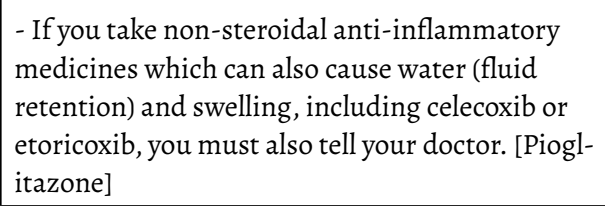
medicines which can also cause water (fluid retention) and swelling, including celecoxib or etoricoxib, you must also tell your doctor. [Pioglitazone]

- Jeśli pacjent przyjmuje leki przeciwzapalne, które mogą powodować zatrzymanie wody w organizmie i obrzęki, należy również poinformować o tym lekarza.

Przykład 5.

Zdarza się też, że w nawiasie podano nazwy stanów ogólnie rozumianych, takich jak „nadwrażliwość", które dodatkowo zostały jeszcze objaśnione przed nawiasem („uczulenie”). „Uczulenie” jest słowem występującym 1,96 razy na milion słów w Narodowym Korpusie Języka Polskiego (dalej NKJP), jednak wyraz „nadwrażliwość”, który ma 1,34 okurencji na milion, ma zbliżoną częstość występowania w korpusie. Inne podobne przykłady redundancji, które - wydaje się niepotrzebnie powtarzają informacje ogólnie rozumiane, to: „utrata zbyt dużej ilości płynów z organizmu (odwodnienie)” czy „jama ropna (ropień)”.

\begin{tabular}{|l|l|}
\hline $\begin{array}{l}\text { - if you are allergic to acarbose or any of the other } \\
\text { ingredients of this medicine }\end{array}$ & $\begin{array}{l}\text { - jeśli pacjent ma uczulenie (nadwrażliwość) na } \\
\text { akarbozę lub którykolwiek z pozostałych skład- } \\
\text { ników leku Glucobay }\end{array}$
\end{tabular}

Przykład 6.

Częstość słów wyjaśnianych przed czy w nawiasie podaje tabela poniżej. Interesujące jest to, że niekiedy w nawiasie podawane są słowa, które są często używane w języku ogólnym, zatem powinny być rozumiane, a jednocześnie nie podaje się objaśnienia do słów trudnych, ogólnie niezrozumiałych. Na przykład, w korpusie polskim objaśnienie „stężenie cukru we krwi” objaśnia termin medyczny podany w nawiasie „glukoza”, który w Narodowym Korpusie Języka Polskiego występuje 2,7 razy na milion słów. Inny przykład to termin „żółtaczka” z okurencją równą 2,3 razy na milion słów według NKJP, który - mimo takiej frekwencji - i tak jest wyjaśniony (przed nawiasem). Wydaje się, że ta tendencja w badanych tekstach może wynikać z dość dosłownego tłumaczenia tekstów oryginalnych.

Tabela 1. przedstawia okurencje wybranych wyrazów po standaryzacji na milion wyrazów wyekscerpowanych z korpusu UP dla danych dostępnych w NKJP. 


\begin{tabular}{|l|l|}
\hline Wyraz & Standaryzacja na milion stów \\
\hline glukoza & 2,7 \\
\hline odwodnienie & 2,6 \\
\hline afazja & 2,5 \\
\hline żółtaczka & 2,3 \\
\hline ropień & 0,4 \\
\hline niedrożność & 0,3 \\
\hline diuretyczny & 0,03 \\
\hline osutka & 0 \\
\hline
\end{tabular}

Tabela 1. Frekwencja wybranych słów według NKJP

$\mathrm{Z}$ jednej strony zatem tłumaczone są słowa o wysokiej frekwencji, w innych przykładach z kolei, jak wcześniej wspomniano, nie podaje się w ogóle objaśnienia danego wyrazu, np. „osutka” (krostkowa). Słowo to ma zerową okurencję w NKJP (zob. tab. 1). Tłumacze z pewnością w dużej mierze odzwierciedlali w tych wypadkach treść ulotek w oryginale, wyjaśniając (lub nie wyjaśniając) znaczenia tych wyrazów, które były definiowane w języku angielskim. Tłumacząc ulotki leków na potrzeby rynku polskiego, należałoby jednak uwzględnić słownictwo polskie i jego cechy pod względem częstości używanych słów w mowie potocznej i ich ogólnej rozpoznawalności (uciekając się do list frekwencyjnych i intuicji rodzimego użytkownika języka polskiego). Ulotka w języku polskim ma bowiem być zrozumiana przez osobę znającą język polski, zatem należy wziąć pod uwagę częstość słów polskich, a nie angielskich.

Dyskusyjne jest podanie słowa „zmęczenie” przed nawiasem i drugiego słowa „znużenie” w nawiasie (Przykład 7.). Nie wiadomo w sumie, które z tych słów jest potraktowane jako termin, a które jako jego objaśnienie. Obydwa słowa są powszechnie używane i zrozumiałe. Ich okurencja na milion słów w NKJP wynosi odpowiednio 18,23 i 3,3.

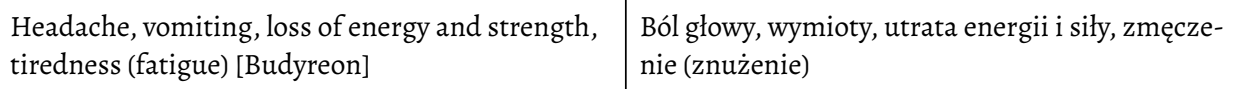

Przykład 7.

Wydaje się zatem, że podanie tylko słowa „zmęczenie” powinno być wystarczające, i - przede wszystkim - trafniej oddaje ono znaczenie oryginału. Co prawda SJP podaje, że znudzenie to „stan osoby znużonej”, a znużenie definiuje jako „stan znudzenia i zmęczenia”, to jednak znudzenie kojarzy się raczej z nudą oraz wynikającego z niej uczucia senności. Zmęczenie natomiast jest raczej konceptualizowane jako stan silniejszy (np. w efekcie ciężkiej pracy fizycznej lub umysłowej) niż wynikający z poczucia nudy. Te intuicyjne różnice w znaczeniu między zmęczeniem i znużeniem uzyskują potwierdzenie w danych korpusowych. NKJP podaje następujące przymiotniki (według parametru MI3, slope -2, +2) współwystępujące z wyrazem zmęczenie i znużenie (Tabela 2): 


\begin{tabular}{|l|l|l|l|}
\hline Zmęczenie & MI3 & Znużenie & MI3 \\
\hline chroniczny & 19,08 & śmiertelny & 12,65 \\
\hline fizyczny & 16,77 & senny & 11,83 \\
\hline pótżywy & 15,43 & wszechogarniający & 11,42 \\
\hline ciagły & 14,74 & ołowiany & 11,13 \\
\hline przewlekty & 14,72 & lekki & 10,98 \\
\hline potworny & 14,32 & ogromny & 10,85 \\
\hline całodzienny & 13,76 & bezgraniczny & 10,75 \\
\hline pótprzytomny & 13,55 & wielki & 10,37 \\
\hline wielki & 13,44 & nagły & 10,11 \\
\hline ogromny & 12,98 & pewny & 8,92 \\
\hline
\end{tabular}

Tabela 2. Wyrazy zmęczenie i znudzenie w kolokacjach (według parametru MI3)

Wyniki te potwierdzają dane z korpusu plTenTen15 (zawierający około 8 miliardów słów, analizowany materiał uwzględnia dane $\mathrm{z}$ internetu), w którym wyraz zmęczenie modyfikowany jest zwykle przez następujące przymiotniki w prepozycji (wynik według statystyki logDice, podkreślenia dotyczą wyrazów, które nie współwystępują z wyrazem znużenie): chroniczny (9,91), przewlekty $(7,92)$, potworny $(7,62)$, ciagty $(7,12)$, permanentny $(7,08)$, nadmierny $(6,66)$, psychiczny $(6,6)$,

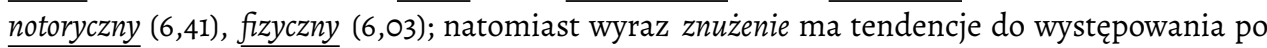
przymiotnikach: niezmierny $(6,08)$, chroniczny $(5,25)$, wszechogarniajacy $(5,12)$, lekki $(3,34)$, potworny $(3,34)$, śmiertelny $(3,3)$, psychiczny $(2,66)$, chwilowy $(2,19)$, umysłowy $(1,83)$, duchowy $(1,81)$. Główne rzeczowniki towarzyszące wyrazowi zmęczenie (np. zmęczenie i senność) to: senność (10.52), stres $(10,03)$, znużenie $(9,45)$, osłabienie $(9,09)$, wyczerpanie $(8,94)$, zniechęcenie $(8,85)$, ból $(8,83)$, itd. Trzy główne rzeczowniki współwystępujące $\mathrm{z}$ wyrazem znużenie natomiast to: senność $(9,48)$, zmęczenie $(9,45)$, zniechęcenie $(9,26)$, w mniejszym stopniu także wyczerpanie $(8,76)$, znudzenie $(8,69)$, apatia $(8,33)$, przesyt $(8,2)$, monotonia $(8,12)$.

$\mathrm{W}$ obu przypadkach występują przymiotniki oznaczające silny stan, jednak w przypadku wyrazu zmęczenie większość wyrazów sygnalizuje wyłącznie ciężki stan (w danych z NKJP wszystkie przymiotniki wymienione powyżej, tj. pierwszych $10 \mathrm{z}$ listy), w tym ból i wyczerpanie oraz jego przewlekły charakter, natomiast w przypadku wyrazu znużony oprócz ciężkiego stanu występują też przymiotniki takie jak lekki, senny, nagły czy chwilowy, a także rzeczowniki apatia, zniecierpliwienie czy monotonia sugerujące lżejsze i krótsze stany. Przymiotnik śmiertelny współwystępujący z wyrazem znużenie użyty jest metaforycznie („Trwał tak przez chwilę, po czym dopadło go śmiertelne znużenie...”). Znużenie wydaje się częściej występujące w sensie metaforycznym.

Podsumowując, podanie słowa znużenie w nawiasie po wyrazie zmęczenie wydaje się być niepotrzebne w tekście polskiej ulotki, ponieważ powtarza ono informacje zawarte w słowie przed nawiasem, nieco je tylko modyfikując, sugeruje bowiem lżejsze stany niż te definiowane przez wyraz zmęczenie. Jak wynika z powyższych danych korpusowych, semantyka słowa zmęczenie nie jest tożsama z semantyką słowa znużenie, choć istnieje wspólny dla nich zakres 
znaczeniowy, ponieważ są to wyrazy bliskoznaczne. $W$ ulotce jednak nie należy podawać w nawiasie synonimów nazw zwyczajowych tylko ich terminy medyczne, a znużenie z pewnością nie jest terminem medycznym słowa zmęczenie. Tłumacz zapewne chciał wiernie przetłumaczyć ulotkę z języka angielskiego, gdzie występuje słowo tiredness („zmęczenie”), a po nim w nawiasie jego odpowiednik używany w terminologii medycznej fatigue („zmęczenie”). Przekład ten można prawdopodobnie wyjaśnić tym, że tłumacze ulotek mają tendencję do dość wiernych tłumaczeń i wprowadzaniu niewielkich tylko modyfikacji, które biorą pod uwagę kontekst kulturowo-społeczny (lub w ogóle ich nie wprowadzając). Uwzględniając strategie tłumaczenia zgodne z teorią lokalizacji (oraz teorią Skopos i podejściem do przekładu znanym jako udomowienie), w ulotce polskiej takie tłumaczenie wydaje się być nieuzasadnione, a nawet mylące.

Kolejnym przykładem jest słowo „ropień, które występuje co prawda w NKJP w niewielkim zakresie, ale intuicja podpowiada, że jest to słowo powszechnie zrozumiałe, bowiem pochodzi od słowa „ropa” (35,1 tysięcy słów na milion w NKJP) i z dużym prawdopodobieństwem będzie zrozumiane przez przeciętnego czytelnika ulotek. Przekładając treść ulotki leków, tłumacz nie powinien się kurczowo trzymać tekstu oryginalnego, tylko uwzględnić specyfikę języka polskiego (zwłaszcza frekwencję słów), bowiem to, co może być zrozumiałe dla czytelnika z kręgu kultury anglojęzycznej, niekoniecznie będzie tak samo zrozumiałe dla rodzimych użytkowników języka polskiego (i odwrotnie).

Celem uzupełnienia, poniżej przedstawiono kilka przykładowych konkordancji zawierających terminy medyczne (lub ich wyjaśnienia) w nawiasach w języku polskim wyekscerpowane z KUP (Ryc. 8.). Przykłady te ilustrują problem frekwencji słów w języku polskim i ich użycia $\mathrm{w}$ charakterze terminu lub objaśnienia. Nie wszystkie terminy poprzedzone są objaśnieniem (przed nawiasem, w którym są umieszczone), jak to zaleca Przewodnik. W suplemencie dla porównania umieszczono też wybrane konkordancje z ulotki w języku angielskim (Ryc. 9).

\begin{tabular}{|c|c|c|}
\hline czynności nerek • niedrożność jelíta & (blokada w jelicie) & • odbijanie się • zaburzenia smaku • zwiększone \\
\hline po podaniu eksenatydu. W tym: jama ropna & (ropień) & i obrzęk, zaczerwieniona skóra z uczuciem \\
\hline polega na zmniejszeniu stężenia cukru & (glukozy) & we krwi. Lek Forxiga jest stosowany w leczeniu \\
\hline \multicolumn{2}{|c|}{ glukozy we krwi, przez co jest odwodniony (utrata zbyt dużej ilości płynów) } & Moźliwe objawy nadmiernej utraty płynów \\
\hline leki pomagające usunąć wodę $\mathrm{z}$ organizmu & (diuretyki) & . Lekarz może zalecić przerwanie stosowania \\
\hline nadmierne zmniejszenie stężenia cukru we krwi & (hipoglikemia) & , objawiające się drżeniem mięśni, nadmierną \\
\hline : utrata zbyt dużej ilości płynów z organizmu & (odwodnienie) & , co zdarza się niezbyt często. Objawy zbytniej \\
\hline hemoglobiny i rozpad krwinek czerwonych & (niedokrwistość hemolityczna) & Przed zastosowaniem gliklazydu należy \\
\hline \multicolumn{3}{|c|}{, zaburzenia mowy i widzenia, afazja (zaburzenia zdolności mówienia) , drżenie, niedowład, zaburzenia czucia, } \\
\hline ), leki wspomagające wytwarzanie moczu & (diuretyki) & , saluretyki, leki stymulujące tarczycę (np. \\
\hline czynnośc wątroby, w tym zażólcenie skóry i oczu & (żóltaczka) & , zaburzenia przepływu żółci (cholestaza), \\
\hline oczu (żóltaczka), zaburzenia przepływu źótci & (cholestaza) & , zapalenie lub niewydolność wątroby. \\
\hline wszystkich komórek krwi), - hiponatremia & (niski poziom sodu we krwi) & , 5 - stany splątania, - bóle głowy, - podwójne \\
\hline leku Glucobay - jeśli pacjent ma uczulenie & (nadwrażliwość) & na akarbozę lub którykolwiek z pozostałych \\
\hline \multicolumn{3}{|c|}{ jelit, zapalenie wątroby, trombocytopenia (zmniejszenie liczby płytek krwi), ostra uogólniona osutka krostkowa W okresie } \\
\hline miał kiedykolwiek niskie ciśnienie tętnicze & (hipotensja) & . Więcej informacji podano poniżej, "Inne leki \\
\hline , zwiększenie liczby czerwonych krwinek & (hematokrytu) & w badaniach krwi. Niezbyt często (może \\
\hline
\end{tabular}

Ryc. 8. Przykładowe konkordancje z korpusu UP

Dodatkowe wyjaśnienia słów (niekoniecznie terminów medycznych), które są stosunkowo często używane, może być przypadkowe, może to być konsekwencja wiernego tłumaczenia z oryginału lub może to świadczyć o dbałości tłumacza o to, aby tekst ulotki był zrozumiały dla 
przeciętnego czytelnika/pacjenta. Należałoby przeprowadzić dalsze badania na większej próbie i/lub badania ankietowe wśród tłumaczy ulotek w celu potwierdzenia danych.

Bez względu na motywację, tłumacze ulotek powinni przekładać teksty tak, aby maksymalnie przybliżyć sens ulotki oryginalnej docelowemu odbiorcy (klientowi, pacjentowi). Takie tłumaczenie wpisuje się w teoretyczny model przekładu, znany jako teoria Skopos (Vermeer 1982), która zakłada właśnie nadrzędność odbiorcy przetłumaczonego tekstu (klienta) i jego potrzeb nad intencje autora tekstu oryginalnego, a także we wcześniej wspomniane podejścia do przekładu znane jako domestykacja oraz lokalizacja. W przypadku ulotek potrzeby osoby czytającej ulotkę leku są szczególnie ważne z uwagi na potencjalne zagrożenia zdrowotne, jakie niesie za sobą niezrozumienie opisu leku.

\section{5 / WNIOSKI}

Ustalenie poziomu czytelności z wykorzystaniem automatycznej analizy tekstu (według wzorów klasycznych i nowszych) pozwoliło zauważyć, że polskie tłumaczenia ulotek charakteryzują się podobnym stopniem czytelności, jak ulotki w języku angielskim. Jednak zarówno ulotki w języku angielskim, jak i polskim napisane są zbyt trudnym językiem, tzn. są mało czytelne (bowiem zrozumiałe na poziomie absolwenta szkoły średniej lub studiów wyższych). Mimo to wydaje się, że polskie tłumaczenia próbują uprościć język oryginału poprzez: częste użycie strony czynnej, preferencje do używania struktur z bezokolicznikiem zamiast rzeczownikiem odsłownym, a także rzadsze użycie rzeczowników abstrakcyjnych niż w ulotkach w języku angielskim. Trzeba pamiętać jednak, że te tendencje mogą wynikać ze specyfiki języka polskiego, a niekoniecznie ze świadomych wyborów tłumacza. Jeśli nawet nie są to celowe wybory tłumaczy, to polskie tłumaczenia zawierają takie strategie tłumaczeniowe, jak uproszczenia i dopowiedzenia, które mogą się przyczynić do zwiększenia zrozumiałości tekstu. Ulotki w języku polskim zawierają więcej wyjaśnień, nawet jeśli nie dotyczą one skomplikowanych terminów medycznych, oraz częściej stosują się do zaleceń podawania w pierwszej kolejności objaśnienia stanu chorobowego czy oznaki/symptomu choroby, a w drugiej kolejności podawania jego terminu medycznego. Ulotki leków są przykładem tekstów użytkowych, zatem przekłady ulotek na język polski powinny dbać o to, aby język był precyzyjny i jednocześnie zrozumiały dla przeciętnego czytelnika na polskim rynku leków. Tłumacz powinien więc uwzględniać frekwencję i specyfikę słów w języku polskim oraz ogólną znajomość pewnych słów na rynku lokalnym (polskim) i niekoniecznie trzymać się kurczowo tekstu źródłowego. Tłumaczenie ulotek leków nie polega bowiem jedynie na przekładzie słów, terminów i fraz, ale również na adaptacji kulturowej tekstu źródłowego do specyfiki uwarunkowań kulturowo-społecznych czytelników przetłumaczonego tekstu.

\section{READABILITY OF TRANSLATED FUNCTIONAL TEXTS: AN AUTOMATED ANALYSIS OF PATIENT INFORMATION LEAFLETS FOR DIABETES}

SUMMARY In recent accounts, readability is most often understood as the level of text difficulty measured in terms of lexico-grammatical aspects of a text. In order to enhance the readability of health-related materials for patients, such as 
drug leaflets, the information should be written in a clear, accessible and understandable way. Interestingly, some approaches to readability encompass both textual parameters as well as readers' competences; however, the term that describes specifically an individual's competencies in reading, understanding and using information on health-related topics is also known as health literacy. It involves the general education level, health-related skills as well as patients' general knowledge. Readability, therefore, depends not only on text characteristics but also on reader characteristics. Another parameter that has a crucial influence on the assessment of text readability is the method of readability measurement. There are a number of the so-called classical readability tests, such as Flesch-Kincaid, Fry, Gunning Fog, Raygor Estimate, SMOG, Flesch Readability Ease, etc. More recently, however, lexico-grammatical indices gain importance over the mechanical methods of counting the number of syllables or letters in a word and the number of words in a sentence, which were typical of the traditional tests.

In this article, some results of the study into the readability level of Patient Information Leaflets (PILs) of drugs for diabetes will be presented. The PILs for diabetes drugs were collected from open source internet resources in order to create a corpus of electronic data. The corpus consists of original leaflets written in English and their Polish translations. Both classical tests (Raygor Readability Estimate, Gunning Fog, Flesch Readability Ease), and several lexico-grammatical calculations (performed with the aid of natural language processing tools available in some applications, such as Coh-Metrix, the Sketch Engine and Jasnopis) were used, compared and correlated. The following lexical and syntactic text features were under inspection: the frequency of words (determined by making reference to the British National Corpus, plTenTen15, and Narodowy Korpus Języka Polskiego), the incidence of nouns (both abstract and concrete), verbs, adjectives, the infinitive, gerund and passive voice. The theoretical framework adopted in the study involved the Descriptive Translation Studies (Toury 1995), localization (Pym 2001), and Corpus-Based Translation Studies (Baker 1993).

\section{LITERATURA}

I Askehave I. - Zethsen K. K., 2014, A comparative analysis of the lay-friendliness of Danish EU patient information leaflets from 2000 to 2012, "Communication and Medicine", 11 (3), s. 209-222.

I Bailin A. - Grafstein A., 2016, Readability: Text and Context, Basingstoke.

I Baker M., 1993, Corpus Linguistics and Translation Studies - implications and applications. Text and Technology, red. M. Baker, G. Francis, E. Tognini-Bonelli, Amsterdam, s. 233-252.

I Bączkowska A., 2019, Readability and lexical sophistication of colon cancer websites - a corpus-assisted assessment of online educational materials for patients, „Forum Filologiczne Ateneum", 1 (7), s. 9-25, https://doi.org/10.36575/2353-2912/1(7)2019.009. 
I Bączkowska A., (w druku a), Automatyczna analiza dyskursu medycznego. Nowoczesne trendy diagnostyki i terapii, red. K. Pawlak-Osińska, M. Śniegocki, M. Szpinda, Toruń.

I Bączkowska A., (w druku b), Dyskurs medyczny a przekład naukowych tekstów medycznych, „Konińskie Studia Językowe/Konin Language Studies”.

I Bormuth J. R., 1966, Readability: a new approach, "Reading Research Quarterly", 1, s. 79-132.

I Bruce B. - Rubin A. - Starr K. S., 1981, Why readability formulas fail. Reading education report no 28, University of Illinois at Urbana-Champaign.

I Buchbinder R. - Hall S. - Grant G. - Mylvaganam A. - Patrick M. R., 2001, Readability and content of supplementary written drug information for patients used by Australian rheumatologists, "Medical Journal of Australia", 174, s. 575-578.

I Charnock D. - Shepperd S. - Needham G. - Gann R., 1999, DISCERN: an instrument for judging the quality of written consumer health information on treatment choices, "Journal of Epidemiology and Community Health", 53, s. 105-111.

I Charzyńska E. - Dębowski Ł. - Gruszczyński W. - Hadryan M., 2015, Historia badań nad zrozumiałością tekstu. Jasnopis, czyli mierzenie zrozumiałości polskich tekstów użytkowych, red. W. Gruszczyński, Ogrodniczuk M. Warszawa, s. 11-38.

I Chesterman A., 2010, Why study translation universals? Kiasm (Acta Translatologica Helsingiensia, 1), red. R. Hartama-Heinonen, P. Kukkonen, Helsinki, s. 38-48, https://helda.helsinki.fi/bitstream/handle/10138/24313/ATH_vol_1\%20Kiasm_30122010. pdf? sequence $=1$ \&isAllowed $=y$

I Clerehan R. - Buchbinder R. - Moodie J., 2005, A linguistic framework for assessing the quality of written patient information: its use in assessing methotrexate information for rheumatoid arthritis, "Health Education Research", 20, s. 334-344.

I Clerehan R. - Hirsh D. - Buchbinder R., 2009, Medication information leaflets for patients: the further validation of an analytic linguistic framework, "Communication and Medicine", 6, s. 117-127.

I Clerehan R., 2014, Quality and usefulness of written communication for patients. The Routlegde Handbook of Language and Health Communication, red. H. Hamilton, S. Chou Wen-Ying, London and New York, s. 212-227.

I Crossley S. A. - Kyle K. - McNamara D. S., 2016, The tool for the automatic analysis of text cohesion (TAACO): Automatic assessment of local, global, and text cohesion, "Behavior Research Methods", 48 (4), s. 1227-1237.

I Crossley S. A. - Skalicky S. - Dascalu M., 2019, Moving beyond classic readability formulas: new methods and new models, "Journal of Research in Reading", 42 (3-4), s. 541-561.

I Davidson A. - Kantor R. N., 1982, On the failure of readability formulas to define readable texts: a case study from adaptations, "Reading Research Quarterly", 17 (2), s. 187-209.

I Davidson A. - Green G. M. (red), 1988, Linguistic Complexity and Text Comprehension: Readability Issues Reconsidered, Hillsdale.

I Esselink B., 2000, A Practical Guide to Localization, Amsterdam.

I Flesch R., 1948, A new readability yardstick, "Journal of Applied Psychology", 32, s. 221-233.

I Garner M. - Ning Z. - Francis, J., 2012, A framework for the evaluation of patient information leaflets, "Health Expectations", 15 (3), s. 283-294.

I Gąsiorek K. - A. Hącia - K. Kłosińska - D. Krzyżyk - J. Nocoń - H. Synowiec., 2014, Kryteria oceny podręcznika szkolnego w aspekcie językowym, www.gov.pl. [dostęp: 30.11.2019]

I Gilliland J., 1968, The concept of readability, "Literacy", 1 (2), s. 24-29.

I Gruszczyński W. - Hadryan M. 2015. Cechy tekstu trudnego. Jasnopis czylimierzenie zrozumiałości polskich tekstów użytkowych, red. W. Gruszczyński, M. Ogrodniczuk, Warszawa, s. 39-75. 
I Gruszczyński W. - Ogrodniczuk M., 2015, Jasnopis czyli mierzenie zrozumiałości polskich tekstów użytkowych, Warszawa.

I Gustafsson J. - Kälvemark S. - Nilsson G. - Nilsson, JLG., 2003, A method to evaluate Patient Information Leaflets, "Therapeutic Innovation and Regulatory Science", 37, s. 115-123.

I Gunning R., 1952, Techniques of Clear Writing, Nowy Jork.

I Hadjipavlou M. - Khan S. - Rane A., 2013, Readability of patient information leaflets for urological conditions and treatments, "Journal of Clinical Urology", 6 (5), s. 302-305.

I Herber O. R. - Gries V. - Schwappach D. - Thürmann P. - Wilm S., 2014, Patient information leaflets: informing or frightening? A focus group study exploring patients' emotional reactions and subsequent behavior towards package leaflets of commonly prescribed medications in family practices, "BMC. Family Pracice", 14, s. 163-171.

I Iluk J., 2012, Wpływ czytelności tekstów edukacyjnych na efektywność nauczania w warunkach szkolnych, „Acta Universitatis Wratislaviensis”, 10 (20), s. 73-89.

I Imiołczyk J., 1987, Prawdopodobieństwo subiektywne wyrazów: podstawowy słownik frekwencyjny języka polskiego, Warszawa.

I Kruger A., 2002, Corpus-based translation research: its development and implications for general, literary and Bible translation, "Acta Theologica", 22 (1), s. 70-106.

I Kruger A. - Wallmach K., 1997, Research methodology for the description of a source texts and its translation(s) - a South African perspective, "South African Journal of African Languages", 17 (4), s. 119-126.

I Leroy G. - Kauchak D. - Mouradi O., 2013, A user-study measuring the effects of lexical simplification and coherence enhancement on perceived and actual text difficulty, "International Journal of Medical Informatics", 82 (8), s. 717-730.

I McNamara D. S. - Graesser A. C. - McCarthy P. M. - Cai Z., 2014, Automated Evaluation of Text and Discourse with Coh-Metrix, Cambridge.

I Montalt V., 2011, Medical translation and interpreting. Handbook of Translation Studies, t. 2, red. Y. Gambier, van L. Doorslaer, Amsterdam, s. 79-84.

I Montalt V. - González-Davis M., 2007, Medical Translation Step by Step: Learning by Drafting, Manchester.

I O'Hagan M. - Ashworth D., 2002, Translation-mediated Communication in a Digital World, Clevedon.

I Pander Maat H. - Lentz L., 2010, Improving the usability of patient information leaflets, "Patient Education and Counseling", 80, s. 113-119.

I Pisarek W., 1969, Jak zmierzyć zrozumiałość tekstu, „Zeszyty Prasoznawcze”, 2/3 (28/29), s. $44-53$.

I Pym A., 2001, Localization and linguistics, http://usuaris.tinet.cat/apym/on-line/translation/ loclinguistics.pdf. [dostęp: 10.11.2019]

I Raygor A. L., 1977, The Raygor readability estimate: a quick and easy way to determine difficulty. Reading: Theory, Research and Practice, Clemson, red. P. D. Pearson, S. C.

I Schäler R., 2010, Localization and translation. Handbook of Translation Studies, vol. 1., red. Y. Gambier, L. van Doorslaer, Amsterdam, s. 209-214.

I Sekhara S. M. - Unnikrishnan M. K. - Vyas N. - Rodrigues G. S., 2017, Development and evaluation of Patient Information Leaflet for Diabetic Foot Ulcer patients, "International Journal of Endocrinology Metabolism", 15 (3), e55454, https://www.ncbi.nlm.nih.gov/pmc/ articles/PMC5702454/ [dostęp: 12.11. 2019]

I Stokes A., 1978, The reliability of readability formulae, "Journal of Research in Reading", 1 (1), s. 21-34. 
I Toury G., 1995, Descriptive Translation Studies and Beyond, Amsterdam.

I Toury G., 2012, Descriptive Translation Studies and Beyond: Revised edition, Amsterdam.

I Tymoczko M., 1998, Computerized corpora and the future of Translation Studies, "Meta", 43 (4), s. 653-659.

I USDDH, 2010. - U.S. Department of Health and Human Services.

I Venuti L., 1995, The Translator's Invisibility: A History of Translation, London.

I Vermeer H. J., 1982, Vom 'richtigen' übersetzen, „Mitteilungsblatt für Dometscher und Übersetzer", 25/4, s. 2-8.

I Wermuth M-C., 2016, Language localization in scientific drug information, "The Journal of Internationalization and Localization", 3 (1), s. 74-94.

I Wolfer S. - Hansen-Morath S. - Konieczny, L., 2015, Are shorter sentences always simpler? Discourse level processing consequences of reformulating jurisdictional texts. Translation and Comprehensibility, red. K Maksymski, S. Gutermuth, S. Hansen-Schirra, Berlin, s. $263-287$.

\section{Suplement:}

\footnotetext{
1 doc\#0 recommended. medicines used to thin the blood 2 doc \#0 contains a sulphonylurea, as low blood sugar 3 doc\#0 frequently, in order to avoid hyperglycaemia 4 doc\#0 with a sulphonylurea, low blood sugar 5 doc \#0 gets them. Severe allergic reactions

6 doc\#0 such as - Swelling of the face, tongue or throat

7 doc $\# 0$

8 doc $\# 0$

9 doc $\# 0$

10 doc\# 1

11 doc\#1

12 doc\# 1

13 doc\#1

14 doc\#1

15 doc\#1

16 doc\# 1

17 doc\#3

18 doc\#3

19 doc\# 3

20 doc\#3

21 doc\#3

22 doc\#3

23 doc\#3

24 doc $\# 4$

25 doc \#4

26 doc\#4

27 doc\#4

28 doc\#4

29 doc\#5

30 doc\#5

31 doc\# 6

32 doc\# 6

33 doc\#8

34 doc\#9

35 doc\#9 Cases of inflammation of the pancreas in most patients) - diarrhoea - hypoglycaemia . These include: cavity containing pus ) and have a history of low blood pressure in your blood which may make you dehydrated of these signs. - if you have or develop nausea prevent you from getting low blood sugar levels contains lactose Forxiga contains lactose chills - burning sensation when passing water taking Forxiga: Common - genital infection ) Medicines supporting muscle build up ): Medicines containing female sex hormones long term (laxatives) Medicines to treat fits to treat nervousness and sleep problems including yellowing of the skin and eyes eyes (jaundice), problems with the bile flow flow (cholestasis), inflammation of the liver , dizziness, drowsiness, headache, shakiness food. Try to avoid alcohol. Alcoholic drinks sugar levels and could cause unconsciousness (tremor), blurred vision, being sick - Eczema allergic) - Pale red, raised, itch bumps or sweets are available from your pharmacist occurring in first 2 or 3 days $\cdot$ increased wind problems, and people taking water tablets are: feeling light-headed or dizzy passing out Lyxumia is taken with metformin) - Drowsiness rapid increase in weight or localised swelling urine, proteins in urine $\cdot$ spinning sensation
}

(anticoagulants) (hypoglycaemia) (high blood sugar) (hypoglycaemia) (anaphylaxis) (angioedema) (pancreatitis)

(low blood sugar) (abscess) (hypotension) , e.g. Warfarin, as you will require additional can occur when combined with Bydureon. if you and diabetic ketoacidosis (a complication of can occur. Hypoglycaemia may reduce your have been reported rarely (may affect up to 1 in - Hypersensitivity (rashes, itching and rapid have been reported uncommonly (may affect up tc when taken with a medicine that contains a and swollen, or red area of skin that feels hot . More information is given below under 'Other

(lose too much body fluid). Possible signs of dehydration are listed at (feeling sick) , vomiting or fever or if you are not able to eat or (hypoglycaemia) . Pregnancy and breast-feeding If you are (milk sugar) . If you have been told by your doctor that you (urinating) - pain in your back or side. Although uncommon, (thrush) of your penis or vagina (signs may include (anabolics) Medicines to inhibit blood clotting (coumarin (oestrogens, progestogens) Medicines to treat high blood pressure called (phenytoin) Medicines to treat high blood pressure or (barbiturates) Medicines to treat infections, tuberculosis ( (jaundice) , problems with the bile flow (cholestasis), (cholestasis) , inflammation of the liver (hepatitis) or (hepatitis) or liver failure. If you experience any of these (tremor) and visual disturbances. (These symptoms may (wine, beer, spirits) can further increase the reduction in blood (hypoglycaemic coma) . Pregnancy and breast-feeding Glipizide must (inflammation of the skin) Not known (frequency cannot be estimated from (urticaria) Page 4 of 5 . . Abnormal liver function Abnormal (chemist) . If you take more Acarbose than you should Get (flatulence) - rumbling in your stomach $\cdot$ a feeling of (diuretics) . Possible signs of dehydration are: feeling (fainting) or feeling dizzy or faint when you stand up very (somnolence) - Injection site reactions (such as itching). (oedema) . If you take Pioglitazone with other medicines (vertigo) - sweating - tiredness - increased appetite 